\title{
Correlates of Emotional and Behavioural Problems in Children with Perinatally Acquired HIV in Cape Town South Africa
}

Publication format dissertation submitted to meet the requirements of the Masters of Philosophy (MPhil) in Liaison Mental Health at the University of Cape Town

Candidate:

Kerry-Ann Louw

Department of Psychiatry and Mental Health

University of Cape Town

Student number LWXKER002

Supervisor:

Jackie Hoare

Department of Psychiatry and Mental Health

University of Cape Town 
i) Declaration 3

ii) Abstract 4

iii) Acknowledgements $\quad 6$

iv) List of tables $\quad 7$

v) Abbreviations $\quad 8$

vi) Chapter 1: Introduction 9

1.1 Context 9

$\begin{array}{ll}1.2 \text { Ethical considerations } & 19\end{array}$

1.3 Author guidelines $\quad 21$

1.4References $\quad 22$

vii) Chapter 2: Publication-ready manuscript 26

2.1 Title page 26

2.2 Abstract 27

2.3 Key words 28

2.4 Background $\quad 29$

2.5 Methods 30

2.6 Results $\quad 35$

2.7 Discussion 37

2.8 Conclusion 41

2.9 References $\quad 42$

2.10 Tables $\quad 45$

2.11 Figures $\quad 52$

viii) Appendices 53

Appendix A= Ethics approval letter 53

Appendix B= Department of Health approval letter 44

Appendix C= Department of Education approval letter 55

Appendix D= Consent form HIV-infected child participants 56

Appendix E= Consent form HIV-negative child participants 63

Appendix F= AIDS Care Instructions for Authors $\quad 70$

Appendix G= Socio-demographic questionnaire $\quad 75$

Appendix $\mathrm{H}=$ Child Behaviour Checklist results across the HIV subgroups 79 


\section{Declaration}

This research is based on independent work performed by the candidate. The candidate was registered for the MPhil degree and working under supervision at the time they began their involvement with the research team. Neither the whole work nor any part has been, is being, or is to be submitted for another degree to any other university. The work has not been reported or published prior to registration for the abovementioned degree.

Date: 13 February 2015

Kerry-Ann Louw 


\begin{abstract}
In the antiretroviral era children perinatally infected with HIV (PHIV+) are surviving into adulthood and are at risk for emotional and behavioural problems. Few studies of these problems have been conducted in low and middle income countries (LMIC) and even fewer in sub-Saharan Africa where the burden of the HIV epidemic remains heaviest. The aims of this study were to provide a quantitative description of emotional and behavioural problems in a group of children and adolescents with perinatally acquired HIV in South Africa compared to a group of well-matched HIV-negative controls and to identify demographic, biological, cognitive and contextual correlates of emotional and behavioural problems.
\end{abstract}

A cross-sectional descriptive, analytical study was conducted. Participants were recruited from community and hospital based clinics. Within the HIV-infected group, children were further divided into three subgroups: PHIV+ children who had never been on antiretroviral therapy (ART naïve), PHIV+ children on ART and PHIV+ children on ART with a confirmed diagnosis of HIV-related encephalopathy (HIVE). Emotional and behavioural problems were assessed using the Child Behaviour Checklist (CBCL). Several measures were used to assess demographic, biological, cognitive and contextual correlates of problem behaviours: socio-demographic questionnaire, clinic records, neuropsychological test battery, Family Resource Scale, Family Support Scale and Center for Epidemiologic Studies-Depression Scale. Children were compared by HIV status on demographic, cognitive and contextual variables as well as the total and subscale scores of the CBCL. Multivariate comparisons of the influence of contextual and cognitive variables on CBCL total problems was performed using a hierarchical step-wise linear regression analytic procedure.

The final sample $(\mathrm{N}=108)$ for data analysis included 78 PHIV+ children and 30 HIV-negative children. Groups were comparable with respect to demographic and contextual variables. Cognitive performance scores were significantly lower in the PHIV+ children when compared to HIV-negative controls $(p<0.001)$. Rates of caregiver depression were higher in both groups than the lifetime prevalence rates reported in the South African population. 
The rate of emotional and behavioural problems in PHIV+ children in this sample (CBCL Total problems in the clinical range $=14 \%$ ) is lower than identified in previous LMIC studies but it is difficult to draw comparisons across studies with different methodologies. According to the final model greater total problems were associated with HIV-infection in children and having a depressed primary caregiver $(\mathrm{F}=8.57, \mathrm{df}=5,102, \mathrm{p}<0.01)$. Caregiver depression was a stronger predictor of total problems in controls $(\beta$ coeff $=0.6091, p<0.001)$ than PHIV + children $(\beta$ coeff $=0.251, p<0.001)$. There was trend level evidence $(\mathrm{p}<0.1)$ toward greater problems in both male and older children. Within the HIV-infected group, HIV subgroup significantly predicted total problems. Children on ART had significantly fewer problems that ART naïve children ( $\beta$ coeff $=7.169, \mathrm{p}<0.001)$, or children on ART with encephalopathy $(\beta$ coeff $=8.095, \mathrm{p}<0.01)$.

This study highlights the need for adequate screening of depression in the caregivers of HIVinfected children. Treating caregiver depression may help reduce emotional and behavioural problems in children in our communities. This study also supports early initiation of ART in order to improve children's quality of life. 


\section{Acknowledgements}

This research is part of a larger study titled Diffusion Tensor Imaging and Neurocognitive Study of ART-naive and ART-treated Children in Cape Town, principal investigator Dr Jackie Hoare, that aims to investigate the neural correlates of cognitive, behavioural and emotional dysfunction in perinatally HIV-infected children. The candidate joined the research team when registered for the MPhil degree and under the supervision of Dr Jackie Hoare. As part of the team the candidate was involved in data management, database development, oversight of study conduct, on-going quality control and research assistant support.

I would like to acknowledge and thank the following people:

My supervisor Jackie Hoare for her support, guidance and encouragement and for allowing me to be a part of this exciting research team.

Nicole Phillips, the project manager, for answering a hundred questions and for always being available to help me clarify my thoughts through this process.

Jonathan Ipser for his assistance with the data analysis and his infinite patience as we tackled the statistical analysis.

Charity Oduro and Bulelwa Mtukushe, the project research assistants, for working with the participants to collect the data and perform the neuropsychological assessments.

Most importantly to the participants and their families for giving up their time to participate in this study. We hope these findings contribute meaningfully to the field and allow us to improve the care we offer. 


\section{List of Tables}

\section{Chapter 1: Introduction}

- Table 1: Studies of Emotional and Behavioural Problems in Perinatally HIV-Infected Youth Conducted in Low and Middle Income Countries (p12)

- Table 2: Variables Correlated with Greater Rates of Emotional and Behavioural Problems in Studies of Emotional and Behavioural Problems in Perinatally HIV-Infected Youth Conducted in Low and Middle Income Countries (p17)

\section{Chapter 2: Publication-ready Manuscript}

- Table 1: Neuropsychological Domains Selected for the Cognitive Performance Score and the Tests from the Neuropsychological Test Battery Used for the Z-score Calculation (p45)

- Table 2: Demographic, Psychological, Contextual and Biological Variables of Children Perinatally Infected with HIV (PHIV+) and HIV-negative Controls (p46)

- Table 3: Demographic, Psychological, Contextual and Biological Variables of Children Perinatally Infected with HIV (PHIV+) Compared by Subgroup: ART Naïve Children, Children on ART and Children on ART with Encephalopathy (p47)

- Table 4: Correlation Matrix Indicating the Relationship Between Contextual Variables (p48)

- Table 5: Prevalence of Internalizing, Externalizing and Total Problem Scores at the Clinical $(>65)$ and Borderline (>60) Cut-off Ranges on the Child Behaviour Checklist of Children Perinatally Infected with HIV (PHIV+) and HIV-negative Controls (p49)

- Table 6: Child Behaviour Checklist Results in Children Perinatally Infected with HIV (PHIV+) and HIV-negative Controls (p50)

- Table 7: Estimates for the Final Model of Total Problems (p51)

- Appendix H: Child Behaviour Checklist Results Across the HIV Subgroups (p79) 


\section{Abbreviations}

- $\mathrm{ADHD}=$ Attention deficit hyperactivity disorder

- AIDS= Acquired immune deficiency syndrome

- $\mathrm{ART}=$ Antiretroviral therapy

- $\mathrm{CBCL}=$ Child Behaviour Checklist (Achenbach \& Ruffle, 2000)

- $\mathrm{CDC}=$ Center for Disease Control and Prevention

- $\quad \mathrm{CDI}=$ Children's Depression Inventory (Trangkasombat \& Likanapichitkul, 1997)

- $\mathrm{CESD}=$ Center for Epidemiological Studies Depression Scale (Radloff, 1977)

- $\mathrm{Cg}=$ Caregiver

- $\mathrm{CHC}=$ Community health clinic

- $\quad$ FRS $=$ Family Resource Scale (Dunst \& Leet, 1987)

- $\quad$ FSS $=$ Family Support Scale (Dunst, Trivette, \& Cross, 1986)

- HAART= Highly active antiretroviral therapy

- $\mathrm{HIV}=$ Human immunodeficiency virus

- $\quad$ HIVE= HIV-related encephalopathy

- $\mathrm{HIV}+=$ HIV-infected youth (behaviourally and/or perinatally infected)

- HIV-= HIV-negative youth

- $\quad$ HTS= Harvard Trauma Scale (Mollica, McDonald, Massagli, \& Silove, 2004)

- ICD-10= International Statistical Classification of Diseases and Related Health Problems

- $\quad \mathrm{LMIC}=$ Low and/or middle income countries

- $\quad \mathrm{PHIV}+=$ Youth perinatally infected with HIV

- $\quad$ PHEU = Perinatally HIV exposed but uninfected youth

- $\quad$ PSC $=$ Paediatric Symptom Checklist (Jellinek et al., 1988)

- $\quad \mathrm{PTSD}=$ Posttraumatic Stress Disorder

- $\mathrm{SD}=$ Standard deviation

- $\quad$ SDQ-P= Strength and Difficulties Questionnaire parent version ("Psychometric properties of the strengths and difficulties questionnaire.," 2001)

- SDQ-P= Strength and Difficulties Questionnaire youth version (Goodman, Meltzer, \& Bailey, 1998)

- $\quad$ SRQ-25= Self Reporting Questionnaire 25 (Harding et al., 1980)

- $\mathrm{Y}=\mathrm{Years}$

- $\quad \mathrm{YSR}=$ Youth Self-Report form (Achenbach, 1991) 


\section{Chapter 1: Introduction}

\subsection{Context}

The burden of the HIV epidemic remains heaviest in sub-Saharan Africa with $69 \%$ of people living with HIV residing in this region (AIDS, 2012). In recent years there have been gains in the management of the HIV epidemic and rates of incident adult HIV infection and AIDS-related mortality rates are declining in South Africa (AIDS, 2012). Expanded access to antiretroviral therapy (ART) has led to accelerated health gains and increased numbers of life-years (AIDS, 2012). Despite these transformations children continue to be infected with HIV and a relatively high proportion of South African children are still vulnerable to being infected with HIV perinatally (PHIV+) (Petersen et al., 2010). More than 90\% of the children who acquired HIV infection in 2011 live in sub-Saharan Africa (AIDS, 2012).

As a result of the decline in AIDS-related mortality, large numbers of PHIV+ children are reaching adolescence and young adulthood. The illness is transforming from a terminal illness to a chronic condition and clinicians are now faced with new challenges in caring for PHIV + children and adolescents. These youth are at increased risk of virus mediated neurocognitive deficits and they face many psychosocial challenges associated with living with a stigmatised illness and in an AIDSaffected family (Boyes \& Cluver, 2014; Cluver, Gardner, \& Operario, 2008; 2007; Hoare et al., 2012; Petersen et al., 2010). Research has focused on the biomedical outcomes in this population but there is an increasing awareness of mental health outcomes given the unique genetic, biological, and social risks children and adolescents face (Mellins \& Malee, 2014).

It has been well documented that children living with other chronic illnesses are at increased risk of psychological distress and behaviour problems (Oguz, Kurul, Dirik, \& Eylül, 2002). International studies have shown that PHIV+ children are also at increased risk of experiencing behavioural and emotional problems (Mellins, Brackis Cott, Dolezal, \& Abrams, 2006; Mellins et al., 2009; Nozyce et al., 2006). Behavioural and emotional problems in these children are important to study because 
they have an impact on adherence to medical treatment, academic performance and quality of life for the individual and their caregivers.

A range of emotional and behavioural problems have been studied in children and adolescents living with HIV. Some studies have used structured psychiatric interviews while others have used symptom checklists of youth or parent reported emotional and behavioural problems to determine prevalence of mental health problems (Mellins \& Malee, 2014). Studies have found elevated rates of a range of psychiatric disorders including depression, anxiety, attention deficit and hyperactivity disorder (ADHD) and disruptive behaviour disorders (Gadow et al., 2010; Kapetanovic et al., 2011; Mellins et al., 2009; Scharko, 2010; Wood, Shah, Steenhoff, \& Rutstein, 2009). Studies have shown increased rates of emotional and behavioural problems in HIV-infected children when compared to HIV-unexposed, negative controls and when compared to HIV-exposed but uninfected children (Bomba et al., 2010; Mellins et al., 2009). Others studies have shown that although the overall rates of behavioural and emotional problems were high, these were not greater than emotional or behaviour problems in HIV-exposed but uninfected children, healthy controls or children living with other chronic illnesses (Ananworanich, Jupimai, Mekmullica, Sosothikul, \& Pancharoen, 2008; Bachanas et al., 2001; Gadow et al., 2010; 2012; Kang, Mellins, Dolezal, Elkington, \& Abrams, 2011; Malee et al., 2011; Mellins et al., 2011).

When reviewing the literature, differences in study methodology and the lack of a standardised assessment of psychosocial problems makes it difficult to draw comparisons across studies. A 2014 review of the literature on mental health functioning of PHIV+ youth by Mellins and Kalee highlights some of the limitations of research in this area (Mellins \& Malee, 2014). Of the 38 studies included by the authors in the review the majority have been conducted in the United States and Europe, few studies used validated psychiatric interviews, behavioural measures were not comparable and not all studies used comparable comparison groups or comparison groups at all (Mellins \& Malee, 2014). 
There have been few studies of the emotional and behavioural problems of PHIV+ youth conducted in low and middle income countries (LMIC). Low socioeconomic status is an independent factor associated with increased rates of psychological and behavioural problems (Wadsworth \& Achenbach, 2005). It is possible that in LMIC the rates of emotional and behavioural problems are high in both HIV-infected and comparison groups because of higher rates of poverty, trauma and adverse life events. A systematic review by Kieling et al reported prevalence rates of $10-20 \%$ of mental health problems in children and adolescents in LMIC (Kieling et al., 2011).

A literature search was conducted to identify studies of emotional and behavioural problems in HIVinfected children living in LMIC. A Pub Med search was conducted including the following search terms: children, adolescents, emotional and behavioural problems, HIV and perinatal HIV infection. Titles, abstracts and methodology of identified articles were reviewed. All articles that reported data on emotional and behavioural problems in PHIV+ children and adolescents that were conducted in LMIC were selected. Few studies were identified therefore articles where it was not made clear whether HIV was perinatally or behaviourally acquired were also included. Table 1 summarises the findings of studies identified by the literature search. 
Table 1: Studies of Emotional and Behavioural Problem in Perinatally HIV-Infected Youth

Conducted in Low and Middle Income Countries

\begin{tabular}{|c|c|c|c|c|}
\hline Study & $\begin{array}{l}\text { Location } \\
\text { and Study } \\
\text { Type }\end{array}$ & Population & $\begin{array}{l}\text { Mental } \\
\text { Health } \\
\text { Measures }\end{array}$ & Outcomes \\
\hline $\begin{array}{l}\text { Ananworanich } \\
2008 \\
\text { (Ananworanich et al., } \\
2008 \text { ) }\end{array}$ & $\begin{array}{l}\text { Thailand } \\
\text { Cross- } \\
\text { sectional }\end{array}$ & $\begin{array}{l}\mathrm{N}=257 \\
\mathrm{n}=66 \mathrm{HIV}+\text { youth } \\
\mathrm{n}=64 \text { children with } \\
\text { haematological/oncological } \\
\text { disease } \\
\mathrm{n}=127 \mathrm{HIV} \text { - } \\
\text { Youth } 6-11 \text { years }\end{array}$ & Cg: CBCL & $\begin{array}{l}\text { No difference in } \\
\text { behavioural and } \\
\text { emotional problems } \\
\text { between the groups } \\
42 \% \text { of all children } \\
\text { had abnormal CBCL } \\
\text { scores } \\
\text { Clinical problems } \\
\text { detected in } 16 \% \text { of } \\
6-11 \text { y group and } \\
27 \% \text { in } 12-16 \text { y } \\
\text { group } \\
\text { Age, gender, CD4 } \\
\text { count and CDC } \\
\text { classification did not } \\
\text { predict problem } \\
\text { behaviours }\end{array}$ \\
\hline $\begin{array}{l}\text { Grover } \\
2007 \\
\text { (Grover, Pensi, \& } \\
\text { Banerjee, 2007) }\end{array}$ & $\begin{array}{l}\text { India } \\
\text { Case-control }\end{array}$ & 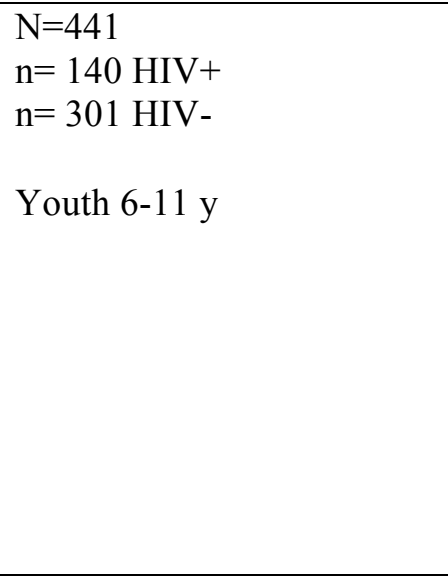 & Cg: CBCL & $\begin{array}{l}\text { Higher rates of } \\
\text { behavioural and } \\
\text { emotional problems } \\
\text { in HIV + youth } \\
(80.7 \%) \text { compared } \\
\text { to HIV- controls } \\
(18.3 \%) \\
\\
\text { Youth from a } \\
\text { disturbed family } \\
\text { environment more } \\
\text { likely to have } \\
\text { behaviour symptoms }\end{array}$ \\
\hline $\begin{array}{l}\text { Lee } \\
2011 \\
\text { (Lee, Chhabra, \& } \\
\text { Oberdorfer, 2011) }\end{array}$ & $\begin{array}{l}\text { Thailand } \\
\text { Cross- } \\
\text { sectional }\end{array}$ & $\begin{array}{l}\mathrm{N}=219 \\
\mathrm{n}=54 \text { PHIV }+ \\
\mathrm{n}=165 \text { HIV- } \\
\text { Youth } \geq 13 \mathrm{y}\end{array}$ & $\begin{array}{l}\text { Youth: Thai } \\
\text { CDI }\end{array}$ & $\begin{array}{l}\text { CDI scores and rates } \\
\text { of clinical } \\
\text { depression }(27.8 \%) \\
\text { were lower in } \\
\text { PHIV+ group } \\
\text { compared to HIV - } \\
\text { controls }(43 \%)\end{array}$ \\
\hline $\begin{array}{l}\text { Louthrenoo } \\
2014 \\
\text { (Louthrenoo, } \\
\text { Oberdorfer, \& } \\
\text { Sirisanthana, 2014) }\end{array}$ & $\begin{array}{l}\text { Thailand } \\
\text { Cross- } \\
\text { sectional }\end{array}$ & $\begin{array}{l}\mathrm{N}=106 \\
\mathrm{n}=50 \text { PHIV }+ \text { on HAART } \\
\mathrm{n}=56 \mathrm{HIV}- \\
\text { Youth } 11-18 \mathrm{y}\end{array}$ & $\begin{array}{l}\text { Youth: YSR } \\
\text { Cg: CBCL }\end{array}$ & $\begin{array}{l}\text { PHIV+ on HAART } \\
\text { reported more } \\
\text { internalizing } \\
\text { problems and lower } \\
\text { competence scores } \\
\text { than controls }\end{array}$ \\
\hline
\end{tabular}




\begin{tabular}{|c|c|c|c|c|}
\hline & & & & $\begin{array}{l}\text { Cg reported greater } \\
\text { impaired social } \\
\text { competence abilities } \\
\text { in PHIV+ on } \\
\text { HAART compared } \\
\text { to controls } \\
\text { Greater viral load } \\
\text { associated with } \\
\text { increased youth } \\
\text { reported behaviour } \\
\text { problems } \\
\text { Living with } \\
\text { caregiver or in foster } \\
\text { care associated with } \\
\text { greater Cg reported } \\
\text { behaviour problems }\end{array}$ \\
\hline $\begin{array}{l}\text { Lowenthal } 2012 \\
\text { (Lowenthal et al., } \\
\text { 2012) }\end{array}$ & $\begin{array}{l}\text { Botswana } \\
\text { Cross- } \\
\text { sectional }\end{array}$ & $\begin{array}{l}\mathrm{N}=692 \mathrm{HIV}+\text { youth } \\
>90 \% \mathrm{n}=\mathrm{PHIV}+ \\
\text { Youth } 8-17 \mathrm{y}\end{array}$ & Cg: PSC & $\begin{array}{l}17.3 \% \text { met symptom } \\
\text { cut off score of } 20 \\
\text { PSC scores were } \\
\text { higher in youth with } \\
\text { virological failure }\end{array}$ \\
\hline $\begin{array}{l}\text { Menon } \\
2007 \\
\text { (Menon, Glazebrook, } \\
\text { Campain, \& Ngoma, } \\
\text { 2007) }\end{array}$ & $\begin{array}{l}\text { Zambia } \\
\text { Cross- } \\
\text { sectional }\end{array}$ & $\begin{array}{l}\mathrm{N}=127 \mathrm{HIV}+\text { youth } \\
\mathrm{n}=123 \text { PHIV+ } \\
\text { Youth } 11-15 \text { y } \\
\text { HIV- age and gender } \\
\text { matched controls from } \\
\text { British community sample }\end{array}$ & $\begin{array}{l}\text { Cg: SDQ-P } \\
\text { Youth: } \\
\text { SDQ-Y }\end{array}$ & $\begin{array}{l}\text { Participants had } \\
\text { increased mental } \\
\text { health problems } \\
\text { compared to a } \\
\text { British community } \\
\text { sample } \\
\text { Disclosure of HIV } \\
\text { status did not have } \\
\text { negative effect on } \\
\text { mental health } \\
\text { Youth reporting } \\
\text { health problems had } \\
\text { higher SDQ-Y } \\
\text { scores }\end{array}$ \\
\hline $\begin{array}{l}\text { Musisi } \\
2009 \\
\text { (Musisi \& Kinyanda, } \\
\text { 2009) }\end{array}$ & $\begin{array}{l}\text { Uganda } \\
\text { Cross- } \\
\text { sectional }\end{array}$ & $\begin{array}{l}\mathrm{N}=82 \mathrm{HIV}+\text { youth } \\
\text { Adolescents }\end{array}$ & $\begin{array}{l}\text { Youth: } \\
\text { SRQ-25 } \\
\text { ICD-10 } \\
\text { criteria }\end{array}$ & $\begin{array}{l}51.2 \% \text { of youth had } \\
\text { significant } \\
\text { psychological } \\
\text { distress } \\
\text { Psychiatric } \\
\text { disorders: anxiety } \\
45.6 \% \text {, somatisation } \\
18.0 \% \text {, mania } \\
1.2 \% \text {, HIV } \\
\text { associated } \\
\text { progressive } \\
\text { encephalopathy } \\
4.8 \%\end{array}$ \\
\hline
\end{tabular}




\begin{tabular}{|c|c|c|c|c|}
\hline $\begin{array}{l}\text { Nöthling } 2013 \\
\text { (Nöthling, Martin, } \\
\text { Laughton, Cotton, \& } \\
\text { Seedat, 2013) }\end{array}$ & $\begin{array}{l}\text { South Africa } \\
\text { Longitudinal }\end{array}$ & $\begin{array}{l}\mathrm{N}=70 \text { mother child dyads } \\
\text { infected with HIV } \\
\text { Child behaviour assessed at } \\
42 \text { months }\end{array}$ & $\begin{array}{l}\text { Cg: CBCL } \\
\text { Cg: CESD } \\
\text { Cg: HTS }\end{array}$ & $\begin{array}{l}44.3 \% \text { children had } \\
\text { total problems in the } \\
\text { clinical range on } \\
\text { CBCL } \\
50 \% \text { had } \\
\text { internalising } \\
\text { problems in clinical } \\
\text { range and } \\
30 \% \text { had } \\
\text { externalizing } \\
\text { problems in clinical } \\
\text { range } \\
\text { 50\% of caregivers } \\
\text { scored above the } \\
\text { cut-off for } \\
\text { depression } \\
\text { Children of mother's } \\
\text { with depression } \\
\text { were significantly } \\
\text { more likely to } \\
\text { display problem } \\
\text { behaviours } \\
\text { Maternal PTSD had } \\
\text { the greatest } \\
\text { explanatory power } \\
\text { for child behaviour } \\
\text { problems, but did } \\
\text { not significantly } \\
\text { predict child } \\
\text { outcomes }\end{array}$ \\
\hline $\begin{array}{l}\text { Petersen } \\
2010 \\
\text { (Petersen et al., 2010) }\end{array}$ & $\begin{array}{l}\text { South Africa } \\
\text { Cross- } \\
\text { sectional }\end{array}$ & $\begin{array}{l}\mathrm{n}=25 \mathrm{HIV}+\text { youth } \\
\mathrm{n}=15 \mathrm{Cg} \\
\text { Youth } 14-16 \mathrm{y}\end{array}$ & $\begin{array}{l}\text { Qualitative } \\
\text { analysis of } \\
\text { in-depth } \\
\text { interviews }\end{array}$ & $\begin{array}{l}\text { Youth reported } \\
\text { multiple } \\
\text { psychosocial } \\
\text { challenges including } \\
\text { loss of parents, } \\
\text { coping with HIV } \\
\text { status, external } \\
\text { stigma and } \\
\text { disclosure } \\
\text { difficulties } \\
\text { Cg reported } \\
\text { disclosure and lack } \\
\text { of financial, family } \\
\text { and social support as } \\
\text { challenges } \\
\text { HIV information, a } \\
\text { future orientation } \\
\text { and social support } \\
\text { identified as } \\
\text { important for coping }\end{array}$ \\
\hline
\end{tabular}




\begin{tabular}{|c|c|c|c|c|}
\hline & & & & $\begin{array}{l}\text { and wellbeing of } \\
\text { youth } \\
\text { Financial and social } \\
\text { support key for } \\
\text { promoting } \\
\text { supportive care- } \\
\text { giving }\end{array}$ \\
\hline $\begin{array}{l}\text { Puthanakit } \\
2013 \\
\text { (Puthanakit et al., } \\
\text { 2013) }\end{array}$ & $\begin{array}{l}\text { Thailand } \\
\text { Cambodia } \\
\text { Longitudinal } \\
\text { study of } \\
\text { early ART } \\
\text { initiation }\end{array}$ & $\begin{array}{l}\mathrm{N}=603 \\
\mathrm{n}=284 \text { PHIV+ } \\
\mathrm{n}=155 \text { PHEU } \\
\mathrm{n}=164 \text { HIV- } \\
\text { Youth } 1-12 \mathrm{y}\end{array}$ & Cg: CBCL & $\begin{array}{l}\text { PHIV+ youth had } \\
\text { higher total and } \\
\text { externalizing } \\
\text { problem scores } \\
\text { when compared to } \\
\text { HIV- controls } \\
\text { CBCL total problem } \\
\text { scores in borderline } \\
\text { clinical range ( }>60) \text { : } \\
16 \% \text { PHIV+ early } \\
\text { ART } \\
20 \% \text { PHIV+ } \\
\text { deferred ART } \\
13 \% \text { PHEU } \\
11 \% \text { HIV- } \\
\text { PHIV+ youth with } \\
\text { lower cognitive } \\
\text { function more likely } \\
\text { to have mental } \\
\text { health problems on } \\
\text { CBCL } \\
\text { Timing of ART } \\
\text { initiation did not } \\
\text { affect behavioural } \\
\text { outcomes }\end{array}$ \\
\hline $\begin{array}{l}\text { Tadesse } \\
2012 \\
\text { (Tadesse, Tsehay, } \\
\text { Belaineh, \& Alemu, } \\
\text { 2012) }\end{array}$ & $\begin{array}{l}\text { Ethiopia } \\
\text { Cross- } \\
\text { sectional }\end{array}$ & $\begin{array}{l}\mathrm{N}=318 \mathrm{HIV}+\text { on HAART } \\
\text { Youth } 6-14 \mathrm{y}\end{array}$ & Cg: CBCL & $\begin{array}{l}39.3 \% \text { of children } \\
\text { had emotional and } \\
\text { behavioural } \\
\text { problems } \\
\text { Low family income, } \\
\text { older age and } \\
\text { parental loss were } \\
\text { found to be } \\
\text { associated with } \\
\text { behavioural and } \\
\text { emotional problems }\end{array}$ \\
\hline
\end{tabular}


- $\quad \mathrm{CBCL}=$ Child Behaviour Checklist (Achenbach \& Ruffle, 2000)

- $\quad \mathrm{CDC}=$ Center for Disease Control and Prevention

- $\quad \mathrm{CDI}=$ Children's Depression Inventory (Trangkasombat \& Likanapichitkul, 1997)

- $\mathrm{CESD}=$ Center for Epidemiological Studies Depression Scale (Radloff, 1977)

- $\mathrm{Cg}=$ Caregiver

- HAART= Highly active antiretroviral therapy

- HIV+= HIV positive youth (behaviourally and/or perinatally infected)

- HIV-= HIV negative youth

- $\quad$ HTS = Harvard Trauma Scale (Mollica et al., 2004)

- ICD-10= International Statistical Classification of Diseases and Related Health Problems

- $\quad$ PHIV $+=$ Youth perinatally infected with HIV

- $\mathrm{PHEU}=$ Perinatally HIV exposed but uninfected youth

- $\quad \mathrm{PSC}=$ Paediatric Symptom Checklist (Jellinek et al., 1988)

- $\mathrm{PTSD}=$ Posttraumatic Stress Disorder

- $\quad$ SDQ-P= Strength and Difficulties Questionnaire parent version ("Psychometric properties of the strengths and difficulties questionnaire.," 2001)

- $\quad$ SDQ-P= Strength and Difficulties Questionnaire youth version (Goodman et al., 1998)

- $\quad$ SRQ-25= Self Reporting Questionnaire 25 (Harding et al., 1980)

- $\quad \mathrm{Y}=$ Years

- $\quad \mathrm{YSR}=$ Youth Self-Report form (Achenbach, 1991) 
These studies show that HIV-infected youth living in LMIC have high rates of emotional and behavioural problems with reported rates between 17 and $80 \%$. As discussed above differences in study design, sample size and symptom measures make it difficult to draw comparisons across these studies. The most commonly used outcome measure of emotional and behavioural problems was the Child Behaviour Checklist. Only one African study included a control group and it can be argued that a British community sample is not a valid comparison group when comparing rates of mental health problems as the control group was only matched for age and gender (Menon et al., 2007).

Several studies in LMIC looked at predictors or correlates of mental health in HIV-infected youth, as summarised in Table 2.

Table 2: Variables Correlated with Greater Rates of Emotional and Behavioural Problems in Studies of Emotional and Behavioural Problems in Perinatally HIV Infected Youth Conducted in Low and Middle Income Countries

\begin{tabular}{|c|c|c|c|}
\hline Demographic Variables & Biological Variables & $\begin{array}{l}\text { Psychological } \\
\text { Variables }\end{array}$ & Contextual Variables \\
\hline Older age ( $>10$ years $)$ & $\begin{array}{l}\text { Virological failure } \\
\text { Greater reporting of } \\
\text { health problems }\end{array}$ & $\begin{array}{l}\text { Lower cognitive } \\
\text { functioning scores }\end{array}$ & $\begin{array}{l}\text { Disturbed family } \\
\text { environment } \\
\text { Living with a } \\
\text { caregiver or in foster } \\
\text { care } \\
\text { Lower income } \\
\text { Parental loss } \\
\text { Caregiver depression } \\
\text { Caregiver } \\
\text { posttraumatic stress } \\
\text { disorder }\end{array}$ \\
\hline
\end{tabular}

Mellins and Malee's review, which included five of the studies in Table 1 (Lee et al., 2011; Lowenthal et al., 2012; Menon et al., 2007; Petersen et al., 2010; Puthanakit et al., 2013), found considerable variability and inconsistency in study findings of correlates of mental health problems in PHIV+ youth (Mellins \& Malee, 2014). Despite the conflicting findings, the reviewers highlight 
the increasing evidence supporting the importance of contextual influences such as caregiver mental health which is associated with PHIV+ youth mental health (Mellins \& Malee, 2014). Caregiver depression has been associated with youth mental health problems in other populations (Billings \& Moos, 1986; Cummings, Keller, \& Davies, 2005; Luoma et al., 2001).

Overall there have been few studies of emotional and behavioural problems in HIV-infected children conducted in LMIC and even fewer studies conducted in the South African context. Cluver has done extensive research looking at mental health outcomes in South African children orphaned by HIV that has shown increased rates of emotional and behavioural problems (Cluver et al., 2008; Cluver, Orkin, Boyes, Gardner, \& Nikelo, 2012; Cluver et al., 2007; Cluver \& Gardner, 2006; 2007; Cluver, Bowes, \& Gardner, 2010). However, this research did not identify the HIV status of the children and has therefore not been included in Table 1 above. Some of these children may have been perinatally infected with HIV.

Local data has value because of the unique biological, psychological and social contextual factors of our population. The aims of this study are to provide a quantitative description of emotional and behavioural problems in a group of PHIV+ children and adolescents in South Africa compared to a group of well-matched HIV-negative controls and to identify demographic, biological, cognitive and contextual correlates of emotional and behavioural problems. An understanding of the rates of emotional and behavioural problems as well as the correlates of these problems in a South African sample can help to motivate for medical, educational and social services for this vulnerable population. 


\subsection{Ethical Considerations}

Ethics approval for this study was obtained from the Human Research Ethics Committee of the Faculty of Health Sciences at the University of Cape Town (HREC REF: 701/2013) (Appendix A). This study was nested in a larger study which obtained ethical approval from the same committee (HREC REF 406/2010). Permission was obtained from both the Department of Health (Appendix B) and the Department of Education (Appendix C) to recruit participants from clinics and schools. This study adheres to the principles of the Declaration of Helsinki (Association, 2008).

Confidentiality: All data collected was kept strictly confidential. Completed instruments and measures were stored in a locked filing cabinet that could only be accessed by the research team. Participants were identified in the database by a participant number only and the database was stored on a secure server. Caregivers and children will not be identified by name in any publications or presentations. Caregivers were asked to give consent for any reports or feedback to be given to the managing medical team or school.

Informed consent: Caregivers were given information about the study purpose, study procedures and risks of and benefits of participation in the study. Caregivers were asked to sign informed consent forms. The consent form was available in English and isiXhosa and provided detailed information regarding the study. The consent form and information form were read to the parents in their own language if they were unable to read the form themselves. There were separate consent forms for HIV-infected (Appendix D) and HIV-negative child participants (Appendix E). Caregivers were asked to provide consent for themselves and their children. All children in the study were below 18 years of age and therefore could not legally give informed consent. Children, where possible, were asked to give assent for their participation in the study. Caregivers and children could withdraw from the study at any time. Participants were not disadvantaged in any way if they chose to withdraw from the study.

Risks of participation: There were no direct physical or psychological risks in participating in the study. Blood was only taken if a recent (less than 3 months) CD4 count or viral load were not 
available. Blood taking was done in line with clinic schedules and standard care in order to minimise discomfort. Blood was taken by a professional licensed to do so.

Some of the questions in the measures asked about sensitive information and may have caused emotional distress to participants. Children may have found the cognitive testing stressful. The research team approached all participants with empathy and sensitivity. Caregivers and children were not coerced into completing any instruments or measures. The testing was spread over time to allow children to have adequate breaks. Children received a certificate and small gift after completion of the study regardless of how many of the instruments or measures were completed. Caregivers and children were not disadvantaged in any way if they were not able to complete the measures.

Some of the instruments and measures detected a possible medical or psychiatric problem. When needed; caregivers and children were referred for medical, psychiatric, psychological and social assessment and intervention.

Benefits of participation: There was no direct benefit to caregivers and children in participating in the study. Reports detailing the findings of the biological, cognitive and behavioural measures were provided (with caregiver consent) to caregivers, schools and managing clinicians. These reports were used to guide clinical decisions and motivate for further assessment and intervention where needed. The findings from the study will be published in a journal and presented at a conference and will hopefully provide useful information to guide clinical practice and resource allocation.

Compensation: Adult participants were compensated with a R50 travel reimbursement and a R50 food voucher. Children were given a certificate and a small prize e.g. T-shirt, pencil bag. 


\subsection{Author Guidelines}

The journal chosen for submission of the manuscript is AIDS Care. AIDS Care is accredited by the South African Department of Higher Education. AIDS Care is a peer reviewed, monthly journal with an impact factor of 2.194 (psc.isr.umich.edu, n.d.). The journal covers a range of HIV/AIDS psychological and socio-medical related subjects including mental health in HIV affected children and youth (tandfonline.com, n.d.). The journal has previously published studies of emotional and behavioural problems in HIV-infected youth conducted in Africa (Tadesse et al., 2012). This journal was chosen because it covers articles on the emotional and behavioural aspects of HIV in children and youth and because it has an appropriate readership which according to the publisher's website includes HIV workers, psychologists, psychiatrists, clinicians, social workers, nurses, health education teachers, Public Health specialists and counselors (tandfonline.com, n.d.). The content of the manuscript would be relevant to this readership and help improve clinical practice. Original articles can be up to 3000 words excluding the abstract, references and tables. The instructions for authors are described in detail in Appendix F. 


\section{References:}

Achenbach, T. M. (1991). Manual for the youth self-report and 1991 profile.

Achenbach, T. M., \& Ruffle, T. M. (2000). The Child Behavior Checklist and related forms for assessing behavioral/emotional problems and competencies. Pediatrics in Review / American Academy of Pediatrics, 21(8), 265-271.

AIDS, J. U. N. P. O. H. (2012). Global report: UNAIDS report on the global AIDS epidemic: 2012.

Ananworanich, J., Jupimai, T., Mekmullica, J., Sosothikul, D., \& Pancharoen, C. (2008). Behavioral and emotional problems in Thai children with HIV infection compared to children with and without other chronic diseases. Journal of the International Association of Physicians in AIDS Care (Chicago, Ill. : 2002), 7(1), 52-53. doi:10.1177/1545109707305173

Association, W. M. (2008). Declaration of Helsinki. Ethical principles for medical research involving human subjects. http://www. wma. net/e/policy/b3. htm.

Bachanas, P. J., Kullgren, K. A., Schwartz, K. S., Lanier, B., McDaniel, J. S., Smith, J., \& Nesheim, S. (2001). Predictors of psychological adjustment in school-age children infected with HIV. Journal of Pediatric Psychology, 26(6), 343-352.

Billings, A. G., \& Moos, R. H. (1986). Children of parents with unipolar depression: a controlled 1year follow-up. Journal of Abnormal Child Psychology, 14(1), 149-166.

Bomba, M., Nacinovich, R., Oggiano, S., Cassani, M., Baushi, L., Bertulli, C., et al. (2010). Poor health-related quality of life and abnormal psychosocial adjustment in Italian children with perinatal HIV infection receiving highly active antiretroviral treatment. Dx.Doi.org, 22(7), 85865. doi:10.1080/09540120903483018

Boyes, M. E., \& Cluver, L. D. (2014). Relationships Between Familial HIV/AIDS and Symptoms of Anxiety and Depression: The Mediating Effect of Bullying Victimization in a Prospective Sample of South African Children and Adolescents. Journal of Youth and Adolescence, 1-13. doi:10.1007/s10964-014-0146-3

Cluver, L. D., Gardner, F., \& Operario, D. (2008). Effects of stigma on the mental health of adolescents orphaned by AIDS. The Journal of Adolescent Health : Official Publication of the Society for Adolescent Medicine, 42(4), 410-417. doi:10.1016/j.jadohealth.2007.09.022

Cluver, L. D., Orkin, M., Boyes, M. E., Gardner, F., \& Nikelo, J. (2012). AIDS-orphanhood and caregiver HIV/AIDS sickness status: effects on psychological symptoms in South African youth. Journal of Pediatric Psychology, 37(8), 857-867. doi:10.1093/jpepsy/jss004

Cluver, L., \& Gardner, F. (2006). The psychological well-being of children orphaned by AIDS in Cape Town, South Africa. Annals of General Psychiatry, 5(1), 8. doi:10.1186/1744-859X-5-8

Cluver, L., \& Gardner, F. (2007). Risk and protective factors for psychological well-being of children orphaned by AIDS in Cape Town: a qualitative study of children and caregivers' perspectives. Dx.Doi.org, 19(3), 318-25. doi:10.1080/09540120600986578

Cluver, L., Bowes, L., \& Gardner, F. (2010). Risk and protective factors for bullying victimization among AIDS-affected and vulnerable children in South Africa. Child Abuse \& Neglect, 34(10), 793-803. doi:10.1016/j.chiabu.2010.04.002

Cluver, L., Gardner, F., \& Operario, D. (2007). Psychological distress amongst AIDS-orphaned children in urban South Africa. Journal of Child Psychology and Psychiatry, and Allied Disciplines, 48(8), 755-763. doi:10.1111/j.1469-7610.2007.01757.x

Cummings, E. M., Keller, P. S., \& Davies, P. T. (2005). Towards a family process model of maternal and paternal depressive symptoms: exploring multiple relations with child and family functioning. Journal of Child Psychology and Psychiatry, and Allied Disciplines, 46(5), 479489. doi:10.1111/j.1469-7610.2004.00368.x

Dunst, C. J., \& Leet, H. E. (1987). Measuring the adequacy of resources in households with young children. Child: Care, Health and Development, 13(2), 111-125.

Dunst, C. J., Trivette, C. M., \& Cross, A. H. (1986). Mediating influences of social support: personal, family, and child outcomes. American Journal of Mental Deficiency, 90(4), 403-417.

Gadow, K. D., Angelidou, K., Chernoff, M., Williams, P. L., Heston, J., Hodge, J., \& Nachman, S. (2012). Longitudinal study of emerging mental health concerns in youth perinatally infected with HIV and peer comparisons. Journal of Developmental and Behavioral Pediatrics : JDBP, 
33(6), 456-468. doi:10.1097/DBP.0b013e31825b8482

Gadow, K. D., Chernoff, M., Williams, P. L., Brouwers, P., Morse, E., Heston, J., et al. (2010). Cooccuring psychiatric symptoms in children perinatally infected with HIV and peer comparison sample. Journal of Developmental and Behavioral Pediatrics : JDBP, 31(2), 116-128. doi:10.1097/DBP.0b013e3181cdaa20

Goodman, R., Meltzer, H., \& Bailey, V. (1998). The Strengths and Difficulties Questionnaire: a pilot study on the validity of the self-report version. European Child \& Adolescent Psychiatry, 7(3), 125-130.

Grover, G., Pensi, T., \& Banerjee, T. (2007). Behavioural disorders in 6-11-year-old, HIV-infected Indian children. Annals of Tropical Paediatrics, 27(3), 215-224. doi:10.1179/146532807X220334

Harding, T. W., de Arango, M. V., Baltazar, J., Climent, C. E., Ibrahim, H. H., Ladrido-Ignacio, L., et al. (1980). Mental disorders in primary health care: a study of their frequency and diagnosis in four developing countries. Psychological Medicine, 10(2), 231-241.

Hoare, J., Fouche, J.-P., Spottiswoode, B., Donald, K., Philipps, N., Bezuidenhout, H., et al. (2012). A diffusion tensor imaging and neurocognitive study of HIV-positive children who are HAART-naïve "slow progressors." Journal of Neurovirology, 18(3), 205-212. doi:10.1007/s13365-012-0099-9

Jellinek, M. S., Murphy, J. M., Robinson, J., Feins, A., Lamb, S., \& Fenton, T. (1988). Pediatric Symptom Checklist: screening school-age children for psychosocial dysfunction. The Journal of Pediatrics, 112(2), 201-209.

Kang, E., Mellins, C. A., Dolezal, C., Elkington, K. S., \& Abrams, E. J. (2011). Disadvantaged neighborhood influences on depression and anxiety in youth with perinatally acquired human immunodeficiency virus: how life stressors matter. Journal of Community Psychology, 39(8), 956-971. doi:10.1002/jcop.20483

Kapetanovic, S., Wiegand, R. E., Dominguez, K., Blumberg, D., Bohannon, B., Wheeling, J., et al. (2011). Associations of Medically Documented Psychiatric Diagnoses and Risky Health Behaviors in Highly Active Antiretroviral Therapy-Experienced Perinatally HIV-Infected Youth. Dx.Doi.org, 25(8), 493-501. doi:10.1089/apc.2011.0107

Kieling, C., Baker-Henningham, H., Belfer, M., Conti, G., Ertem, I., Omigbodun, O., et al. (2011). Child and adolescent mental health worldwide: evidence for action. Lancet, 378(9801), 15151525. doi:10.1016/S0140-6736(11)60827-1

Lee, B., Chhabra, M., \& Oberdorfer, P. (2011). Depression among Vertically HIV-Infected Adolescents in Northern Thailand. Journal of the International Association of Providers of AIDS Care (JIAPAC), 10(2), 89-96. doi:10.1177/1545109710397892

Louthrenoo, O., Oberdorfer, P., \& Sirisanthana, V. (2014). Psychosocial functioning in adolescents with perinatal HIV infection receiving highly active antiretroviral therapy. Journal of the International Association of Providers of AIDS Care (JIAPAC), 13(2), 178-183. doi:10.1177/2325957413488171

Lowenthal, E., Lawler, K., Harari, N., Moamogwe, L., Masunge, J., Masedi, M., et al. (2012). Rapid psychosocial function screening test identified treatment failure in HIV+ African youth. AIDS Care, 24(6), 722-727. doi:10.1080/09540121.2011.644233

Luoma, I., Tamminen, T., Kaukonen, P., Laippala, P., Puura, K., Salmelin, R., \& Almqvist, F. (2001). Longitudinal study of maternal depressive symptoms and child well-being. Journal of the American Academy of Child and Adolescent Psychiatry, 40(12), 1367-1374. doi:10.1097/00004583-200112000-00006

Malee, K. M., Tassiopoulos, K., Huo, Y., Siberry, G., Williams, P. L., Hazra, R., et al. (2011). Mental health functioning among children and adolescents with perinatal HIV infection and perinatal HIV exposure. Dx.Doi.org, 23(12), 1533-44. doi:10.1080/09540121.2011.575120

Mellins, C. A., \& Malee, K. M. (2014). Understanding the mental health of youth living with perinatal HIV infection: lessons learned and current challenges. Journal of the International AIDS Society, 16(1), 18593. doi:10.7448/ias.16.1.18593

Mellins, C. A., Brackis Cott, E., Dolezal, C., \& Abrams, E. J. (2006). Psychiatric disorders in youth with perinatally acquired human immunodeficiency virus infection. The Pediatric Infectious Disease Journal, 25(5), 432-437. doi:10.1097/01.inf.0000217372.10385.2a 
Mellins, C. A., Brackis Cott, E., Leu, C. S., Elkington, K. S., Dolezal, C., Wiznia, A., et al. (2009).

Rates and types of psychiatric disorders in perinatally human immunodeficiency virus-infected youth and seroreverters. Journal of Child Psychology and Psychiatry, 50(9), 1131-1138. doi:10.1111/j.1469-7610.2009.02069.x

Mellins, C. A., Tassiopoulos, K., Malee, K., Moscicki, A.-B., Patton, D., Smith, R., et al. (2011). Behavioral Health Risks in Perinatally HIV-Exposed Youth: Co-Occurrence of Sexual and Drug Use Behavior, Mental Health Problems, and Nonadherence to Antiretroviral Treatment. Dx.Doi.org, 25(7), 413-22. doi:10.1089/apc.2011.0025

Menon, A., Glazebrook, C., Campain, N., \& Ngoma, M. (2007). Mental health and disclosure of HIV status in Zambian adolescents with HIV infection: implications for peer-support programs. Journal of Acquired Immune Deficiency Syndromes (1999), 46(3), 349-354. doi:10.1097/QAI.0b013e3181565df0

Mollica, R. F., McDonald, L., Massagli, M., \& Silove, D. M. (2004). Measuring trauma, measuring torture. Cambridge.

Musisi, S., \& Kinyanda, E. (2009). Emotional and behavioural disorders in HIV seropositive adolescents in urban Uganda. East African Medical Journal, 86(1), 16-24.

Nozyce, M. L., Lee, S. S., Wiznia, A., Nachman, S., Mofenson, L. M., Smith, M. E., et al. (2006). A Behavioral and Cognitive Profile of Clinically Stable HIV-Infected Children. Pediatrics, 117(3), 763-770. doi:10.1542/peds.2005-0451

Nöthling, J., Martin, C. L., Laughton, B., Cotton, M. F., \& Seedat, S. (2013). Maternal posttraumatic stress disorder, depression and alcohol dependence and child behaviour outcomes in mother-child dyads infected with HIV: a longitudinal study. BMJ Open, 3(12), e003638e003638. doi:10.1136/bmjopen-2013-003638

Oguz, A., Kurul, S., Dirik, E., \& Eylül, D. (2002). Relationship of Epilepsy-Related Factors to Anxiety and Depression Scores in Epileptic Children. Journal of Child Neurology, 17(1), 37 40. doi:10.1177/088307380201700109

Petersen, I., Bhana, A., Myeza, N., Alicea, S., John, S., Holst, H., et al. (2010). Psychosocial challenges and protective influences for socio-emotional coping of HIV+ adolescents in South Africa: a qualitative investigation, 22(8), 970-8. doi:10.1080/09540121003623693

psc.isr.umich.edu. (n.d.). psc.isr.umich.edu. Retrieved January 30, 2015, from http://www.psc.isr.umich.edu

Psychometric properties of the strengths and difficulties questionnaire. (2001). Psychometric properties of the strengths and difficulties questionnaire. Journal of the American Academy of Child and Adolescent Psychiatry, 40(11), 1337-45. doi:10.1097/00004583-200111000-00015

Puthanakit, T., Ananworanich, J., Vonthanak, S., Kosalaraksa, P., Hansudewechakul, R., van der Lugt, J., et al. (2013). Cognitive function and neurodevelopmental outcomes in HIV-infected Children older than 1 year of age randomized to early versus deferred antiretroviral therapy: the PREDICT neurodevelopmental study. The Pediatric Infectious Disease Journal, 32(5), 501508. doi:10.1097/INF.0b013e31827fb19d

Radloff, L. S. (1977). The CES-D Scale A Self-Report Depression Scale for Research in the General Population. Applied Psychological Measurement, 1(3), 385-401. doi:10.1177/014662167700100306

Scharko, A. M. (2010). DSM psychiatric disorders in the context of pediatric HIV/AIDS. Dx.Doi.org, 18(5), 441-5. doi:10.1080/09540120500213487

Tadesse, A. W., Tsehay, Y. B., Belaineh, B. G., \& Alemu, Y. B. (2012). Behavioral and emotional problems among children aged 6-14 years on highly active antiretroviral therapy in Addis Ababa: A cross-sectional study. Dx.Doi.org, 24(11), 1359-67. doi:10.1080/09540121.2011.650677

tandfonline.com. (n.d.). tandfonline.com. Retrieved January 30, 2015, from http://www.tandfonline.com

Trangkasombat, U., \& Likanapichitkul, D. (1997). The Children's Depression Inventory as a screen for depression in Thai children. Journal of the Medical Association of Thailand = Chotmaihet Thangphaet, 80(8), 491-499.

Wadsworth, M. E., \& Achenbach, T. M. (2005). Explaining the Link Between Low Socioeconomic Status and Psychopathology: Testing Two Mechanisms of the Social Causation Hypothesis. 
Journal of Consulting and Clinical Psychology, 73(6), 1146-53. doi:10.1037/0022006X.73.6.1146

Wood, S. M., Shah, S. S., Steenhoff, A. P., \& Rutstein, R. M. (2009). The impact of AIDS diagnoses on long-term neurocognitive and psychiatric outcomes of surviving adolescents with perinatally acquired HIV. AIDS (London, England), 23(14), 1859-1865.

doi:10.1097/QAD.0b013e32832d924f 


\section{Chapter 2: Publication-ready manuscript}

\section{Title Page}

Correlates of Emotional and Behavioural Problems in Children with Perinatally Acquired HIV in Cape Town South Africa

Authors:

Kerry-Ann Louw (corresponding author)

University of Cape Town Department of Psychiatry and Mental Health

Anzio Road Observatory, 7925, Cape Town South Africa

0214042151, kerry.louw@uct.az.za

Nicole Phillips

University of Cape Town Department of Psychiatry and Mental Health

Anzio Road Observatory, 7925, Cape Town South Africa

0214042151,nicole.phillips@uct.ac.za

Jonathan Ipser

University of Cape Town Department of Psychiatry and Mental Health Anzio Road Observatory, 7925, Cape Town South Africa

0214042151,jonathan.ipser@uct.ac.za

Jacqueline Hoare

University of Cape Town Department of Psychiatry and Mental Health Anzio Road Observatory, 7925, Cape Town South Africa

0214042151,hoare.jax@gmail.com

This work has been supported by the NRF Thuthuka programme. 


\begin{abstract}
In the antiretroviral (ART) era children perinatally infected with HIV (PHIV+) are surviving into adulthood and are at risk for emotional and behavioural problems. Few studies of these problems have been conducted in low and middle income countries and even fewer in sub-Saharan Africa where the burden of the HIV epidemic remains heaviest. The aims of this study were to provide a quantitative description of emotional and behavioural problems in a group of PHIV + children and adolescents in South Africa compared to a group of well-matched HIV-negative controls and to identify demographic, biological, cognitive and contextual correlates of emotional and behavioural problems.
\end{abstract}

A cross-sectional descriptive, analytical study was conducted. Participants were recruited from community and hospital based clinics. Emotional and behavioural problems were assessed using the Child Behaviour Checklist (CBCL). Several measures were used to assess demographic, biological, cognitive and contextual correlates of problem behaviours. Children were compared by HIV status on demographic, cognitive and contextual variables as well as the total and subscale scores of the CBCL. Multivariate comparisons of the influence of contextual and cognitive variables on CBCL total problems was performed using a hierarchical step-wise linear regression analytic procedure.

According to the final model greater problems were associated with HIV-infection in children and having a depressed primary caregiver $(\mathrm{F}=8.57, \mathrm{df}=5,102, \mathrm{p}<0.01)$. In the HIV group, children on ART had significantly fewer problems that ART naïve children ( $\beta$ coeff $=7.169, \mathrm{p}<0.001)$, or children on ART with encephalopathy $(\beta$ coeff $=8.095, \mathrm{p}<0.01)$.

This study highlights the need for adequate screening of depression in the caregivers of HIVinfected children. Treating caregiver depression may help reduce emotional and behavioural problems in children in our communities. This study also supports the early initiation of ART in order to improve children's quality of life. 
Key words

Emotional and behavioural problems, children, adolescents, HIV, CBCL, perinatal HIV infection, caregiver depression 


\section{Main text}

\section{Background}

The burden of the HIV epidemic remains heaviest in sub-Saharan Africa with $69 \%$ of people living with HIV residing in this region (AIDS, 2012). Despite gains in the management of HIV a relatively high proportion of South African children are still vulnerable to being infected with HIV perinatally (PHIV+) (Petersen et al., 2010). PHIV+ children are living longer in the antiretroviral (ART) era and they face challenges of virus mediated neurocognitive deficits and psychosocial difficulties associated with living with a stigmatised illness and in AIDS-affected families (Boyes \& Cluver, 2014; Cluver, Gardner, \& Operario, 2008; 2007; Hoare et al., 2012; Petersen et al., 2010).

It has been well documented that children living with other chronic illnesses are at increased risk of psychological distress and behaviour problems (Oguz, Kurul, Dirik, \& Eylül, 2002). Studies in Europe and the United States have shown increased rates of emotional and behavioural problems in HIV-infected children when compared to HIV-exposed but uninfected children and HIV-negative controls (Bomba et al., 2010; Mellins et al., 2009; Menon, Glazebrook, Campain, \& Ngoma, 2007). Others studies have shown that although the overall rates of behavioural and emotional problems were high these were not greater than emotional or behaviour problems in HIV-exposed but uninfected children, healthy controls or children living with other chronic illnesses (Bachanas et al., 2001; Gadow et al., 2010; Kang, Mellins, Dolezal, Elkington, \& Abrams, 2011; Malee et al., 2011; Mellins et al., 2011). One of the major limitations of the literature is that overall there have been few studies of emotional and behavioural problems in HIV-infected children conducted in low and middle income countries (LMIC) (Mellins \& Malee, 2014).

Studies conducted in LMIC have found high rates (17-80\%) of emotional and behavioural problems in HIV-infected children (Ananworanich, Jupimai, Mekmullica, Sosothikul, \& Pancharoen, 2008; Grover, Pensi, \& Banerjee, 2007; Louthrenoo, Oberdorfer, \& Sirisanthana, 2014; Lowenthal et al., 2012; Menon et al., 2007; Musisi \& Kinyanda, 2009; Nöthling, Martin, Laughton, Cotton, \& Seedat, 2013; Puthanakit et al., 2013; Tadesse, Tsehay, Belaineh, \& Alemu, 2012). Few LMIC studies have 
included control groups and across studies these control groups are not comparable (Ananworanich et al., 2008; Grover et al., 2007; Lee, Chhabra, \& Oberdorfer, 2011; Louthrenoo et al., 2014; Menon et al., 2007; Puthanakit et al., 2013). Reported rates of emotional and behavioural problems have been both greater than (Grover et al., 2007; Louthrenoo et al., 2014; Puthanakit et al., 2013) and equal to rates in HIV-negative controls (Ananworanich et al., 2008).

There is considerable variability and inconsistency in study findings of correlates of mental health problems in PHIV+ youth (Mellins \& Malee, 2014). Despite conflicting findings there is increasing evidence supporting the importance of contextual influences especially caregiver mental health which is associated with PHIV+ youth mental health (Mellins \& Malee, 2014). Studies conducted in LMIC have identified several correlates of greater emotional and behaviour problems in HIVinfected children including older child age, greater viral load, lower cognitive function, higher health problems, lower income, loss of parents, disturbed family environment, living with a caregiver or in foster care, caregiver depression and caregiver posttraumatic stress disorder (PTSD) (Grover et al., 2007; Louthrenoo et al., 2014; Lowenthal et al., 2012; Nöthling et al., 2013; Puthanakit et al., 2013; Tadesse et al., 2012).

The aims of this study are to provide a quantitative description of emotional and behavioural problems in a group of PHIV+ in South Africa compared to a group of well-matched HIV-negative controls and to identify demographic, biological, cognitive and contextual correlates of emotional and behavioural problems.

\section{Methods}

\section{Study design}

A cross-sectional descriptive, analytical study was conducted on a group of PHIV+ children ages 616 years and a comparison group of HIV-negative, unexposed children from the same socioeconomic communities. 


\section{Sample}

PHIV+ children were recruited from Infectious Diseases clinics at Khayelitsha Site C, Woodstock and Mitchells Plain Community Health Clinics (CHCs) as well as the paediatric neurology service at Red Cross War Memorial Children's Hospital and the Groote Schuur Hospital Paediatric HIV clinic in Cape Town, South Africa. A positive diagnosis of HIV including confirmatory tests was an inclusion criterion. Caregivers were asked whether transmission was perinatal and as far as possible this was confirmed by reviewing clinical records. Within the HIV-infected group, children were further divided into three subgroups: PHIV+ children who had never been on antiretroviral therapy (ART naïve), PHIV+ children on ART and PHIV+ children on ART with a confirmed diagnosis of HIV-related encephalopathy.

HIV-negative, unexposed control children were recruited from schools and by word of mouth in the same communities as the CHCs. Controls were matched for age, gender, language and race.

This study formed part of a larger study which included brain imaging therefore children with other serious medical comorbidities, previous central nervous system conditions, previous head injuries, a history of drug or alcohol exposure in pregnancy, a history of perinatal complications that could have caused brain injury or any contra-indication to magnetic resonance imaging were excluded.

\section{Study procedure}

Ethics approval for this study was obtained from the Human Research Ethics Committee of the Faculty of Health Sciences at the University of Cape Town (HREC REF: 701/2013). Permission was obtained from both the Department of Health and the Department of Education to recruit participants from clinics and schools. Caregivers had to be able to provide fully informed consent for the child to participate in the study. Any subjects who were diagnosed with medical or psychiatric conditions during the study were referred for further assessment and management. 


\section{Measures}

All instruments used were translated into isiXhosa and back-translated into English by qualified translators at the University of Stellenbosch Language Center. The instruments were administered by two researchers, a clinical social worker and a psychology masters student, who received training in the instruments from a neuropsychologist. The researchers administering these instruments were fluent in English and isiXhosa.

\section{Emotional and behavioural problems}

The main outcome measure of this study was emotional and behavioural problems which was measured using the Child Behaviour Checklist CBCL/6-18 version (Achenbach \& Ruffle, 2000). The CBCL/6-18 is a standardised caregiver rating scale used to identify emotional and behavioural problems in children between ages 6 and 18 years. Caregiver was defined in this study as the person taking primary responsibility for caring for the child. The CBCL has 113 problem behaviour items. Caregivers respond using a 3 -point Likert scale $(0=$ Not True, $1=$ Somewhat or Sometimes True, $2=$ Very true or Often True) based on observed behaviour over the previous 6 months. The CBCL has been used globally in clinical and research settings and it has been validated in non-English speaking children from varying social groups and with varying physical and mental health conditions (Albores-Gallo et al., 2007; Tadesse et al., 2012). The CBCL preschool version has been used successfully to measure emotional and behavioural problems in South African children (Nöthling et al., 2013).

\section{Demographic Variables}

Child age and gender were asked about in a socio-demographic questionnaire (Appendix G). Age was analysed as a dichotomous variable; participants ages 10 years or older were grouped as adolescents and participants younger than 10 years of age as children. This cut-off is consistent with World Health Organization definition of adolescence (World Health Organization, 2014). 


\section{Biological Variables}

Child HIV status was confirmed by reviewing clinical records for a confirmatory Elisa test. CD4 count and viral load (VL) were determined by reviewing clinical records. Blood samples were taken if a recent (less than 3 months) test was not available. VL was analysed as a dichotomous variable because of the extreme values with VL less or equal to 40 being classed as undetectable versus VL greater than 40. ART schedule was obtained from the participant's clinical records. $H I V$ encephalopathy was determined by a neuromedical examination performed on all HIV-infected children by a paediatric neurodevelopmental specialist.

\section{Psychological Variables}

A Cognitive performance score for children was calculated as an average of z-scores from a battery of neuropsychological tests. For large test batteries with age adjustment and normative data (WASI, TEA-ch, Nepsy) the scaled scores were used in the z-score calculation. Scaled scores were calculated according to the normative scores provided in individual test manuals or using the appropriate software. For timed tests and all other tests the raw scores were used in the z-score calculation. Cognitive domains known to be affected in PHIV+ children were selected for the calculation (Laughton, Cornell, Boivin, \& Van Rie, 2013) (Table 1). All instruments are standardized, have good psychometric properties and have been used in paediatric neuropsychology research and clinical assessment in South Africa (Hoare et al., 2012).

\section{Contextual Variables}

Relationship of caregiver to the child was asked about in the socio-demographic questionnaire. Caregivers were classified into two groups; biological father or biological mother and other.

Household crowding was measured using information from the socio-demographic questionnaire and calculated as number of people living in the house divided by number of rooms.

The Family Resources Scale (FRS) is a standardized 30-item scale used to assess the extent to which resources are perceived to be adequate in households of young children (Dunst \& Leet, 1987). 
Caregivers rate the extent to which each of the resources is adequate on a 5 point Likert scale $(1=$ Not at all adequate, $2=$ Seldom adequate, $3=$ Sometimes adequate, $4=$ Usually adequate, $5=$ Almost always adequate). The FRS has been shown to be a reliable and valid tool for assessing perceived adequacy of resources among economically diverse families of children with emotional and behavioural disorders (Brannan, Manteuffel, Holden, \& Heflinger, 2006). The FRS has not been used in previously-published HIV-related studies of South African samples.

The Family Support Scale (FSS) is a standardized 18-item scale used to assess caregivers' satisfaction with the perceived level social support they receive in raising young children (Dunst, Trivette, \& Cross, 1986). Caregivers rate how helpful various sources of support have been in terms of raising their children on a 5 point Likert scale $(1=$ Not at all helpful, $2=$ Sometimes helpful, $3=$ Generally helpful, $4=$ Very helpful, $5=$ Extremely helpful). The internal consistency and test-retest reliability of the FRS have been found to be moderately high in studies of low-income families (Hanley, Tassé, Aman, \& Pace, 1998). The FSS has not been used in previously-published HIVrelated studies of South African samples.

Caregiver depression was measured using the Center for Epidemiologic Studies-Depression Scale (CESD) a 20 item self-report scale designed to measure depression symptomatology in the general population (Radloff, 1977). The CES-D measures common symptoms of major depression such as low mood, feelings of guilt and worthlessness, psychomotor retardation, loss of appetite, and sleep disturbance. Caregivers rate how often they have felt or behaved in a certain way in the previous week on a 3 point Likert scale $(0=$ Rarely or None of the Time, $1=$ Some or little of the Time, $2=$ Moderately or Much of the Time, $3=$ Most or Almost All the Time). The CESD has been validated in South Africa and has been shown to be an effective screening tool for depression in HIV-infected adults (Landon et al., 2008; Singh, Sunpath, John, Eastham, \& Gouden, 2008). A cut-off score of 16 is considered to be depression and has been used in previous South African studies (Nöthling et al., 2013). 


\section{Data analysis}

Data was captured into an Excel spread sheet and analyses were conducted using the R statistical computing language (version 3.1.2). Children were compared by HIV status on demographic, psychological and contextual variables, as well as the total and subscale scores of the CBCL. Chisquare tests were conducted for categorical variables, with continuous data compared by means of two-sample t-tests, or the non-parametric Mann-Whitney tests where assumptions of normality were violated.

Multivariate comparisons of the influence of contextual and cognitive variables on CBCL total problems was performed using a hierarchical step-wise linear regression analytic procedure. A block of contextual variables was added to a basic model including HIV status and children's age and gender as nuisance covariates. An iterative model comparison algorithm was subsequently run, as implemented using R's step function, in which variables that made the least contribution to model fit (as assessed using the AIC metric) were removed in a step-wise fashion from the model. The final model was attained when removal of any additional variables would result in a statistically significant decrement in model fit. In order to ensure that the final model selection was not dominated solely by the statistical properties of the data, the influence of cognitive performance was only assessed after the backward stepwise function had identified significant predictor terms from the block of contextual variables, as well as their interactions with HIV status.

\section{Results}

A total number of 120 children and adolescents were recruited. The final sample $(\mathrm{N}=108)$ for data analysis included 78 PHIV+ children and 30 HIV-negative control children. The demographic, psychological and contextual variables are compared between the two groups in Table 2 . The mean age of children in this study was 10 years split approximately equally in children $(50.9 \%)$ and adolescents $(49.1 \%)$. The groups were comparable with respect to demographic and contextual variables. Cognitive performance scores were significantly lower in the PHIV + children when compared to the HIV-negative controls $(\mathrm{p}<0.001)$. Using a cut-off of 16 on the CESD, $43.6 \%$ of 
caregivers of PHIV+ children and 50\% of caregivers of HIV-negative controls screened positive for depression with no significant difference between groups.

The demographic, psychological, contextual and biological variables are compared between the three subgroups in Table 3. The demographic variables are comparable between the subgroups except for the encephalopathy group being younger than the ART treated group. The psychological and contextual variables were not significantly different between the groups. There was trend-level evidence $(\mathrm{p}<0.1)$ for greater perceived resources in the encephalopathy group. For the biological variables, viral loads were significantly higher in the ART-naïve group (60\% detectable) when compared to the ART-treated ( $21 \%$ detectable) and encephalopathy groups $(11 \%$ detectable $)(\mathrm{p}=$ 0.01) while CD4 count was significantly lower in the ART-naïve group when compared to the ARTtreated and encephalopathy groups $(\mathrm{p}=0.02)$.

Table 4 shows a correlation matrix indicating the relationships between the contextual variables for the total sample. Greater depression was significantly associated with lower perceived resources $(\mathrm{p}=$ 0.01 ) and there is a significant positive correlation between FRS and FSS scores.

Table 5 shows the prevalence of internalizing, externalizing and total problems in the PHIV+ children and control group at the clinical $(>65)$ and borderline $(>60)$ cut-off ranges of the CBCL. There are no statistically significant differences in between group comparisons.

Table 6 shows the CBCL scores and between group comparisons for the PHIV+ children and HIVnegative control children. No statistically significant differences were observed in the between group univariate tests of CBCL total, internalizing and externalizing problem scores. The somatic problems subscale $(\mathrm{p}=0.06)$ trended towards being significantly greater in the PHIV + group when compared to controls.

Appendix $\mathrm{H}$ shows the CBCL results across the three HIV subgroups. Some variability was observed with respect to the distribution of total problem scores between these groups, with children on ART having fewer emotional and behavioural problems when compared to ART naïve and children on ART with encephalopathy $(\mathrm{F}=6.188, \mathrm{df}=2.75, \mathrm{p}<0.01)$. 
After controlling for gender and age, the contextual variables retained following step-wise regression included caregiver depression and the interaction between caregiver depression and HIV status. The regression model of total problems on HIV status and depression, as well as their interaction, was significant $(\mathrm{F}=8.57, \mathrm{df}=5,102, \mathrm{p}<0.01)$, explaining over a quarter of the variability in total problems (adjusted $\mathrm{R}^{2}=26.1 \%$ ). The addition of the cognitive performance variable did not improve the prediction of total problems. Table 7 shows the estimates for the final model of total problems.

According to the final model, greater problems were associated with HIV-infection in children and having a depressed primary caregiver. There was trend-level evidence $(\mathrm{p}<0.1)$ for greater problems in both male and older children. Depression was a stronger predictor of total problems in controls ( $\beta$ coeff $=0.6091, \mathrm{p}<0.001)$ than PHIV + children $(\beta$ coeff $=0.251, \mathrm{p}<0.001)$, after controlling for child gender and age. Figure 1 shows a scatter plot of the interaction between HIV status, caregiver depression and CBCL Total Problem scores. In a model assessing the effect of biological variables (HIV subgroup, CD4 count, viral load) within the HIV-infected participants, only HIV subgroup significantly predicted total problems. The ART treated group presented with fewer problems than either the PHIV+ children on ART with encephalopathy ( $\beta$ coeff $=8.095, \mathrm{p}<0.01)$ or the ART naïve children $(\beta$ coeff $=7.169, p<0.001)$, with equally high rates of total problems in the latter two groups $(\beta$ coeff $=-0.926, p=0.738)$.

\section{Discussion}

This study examined the prevalence and correlates of emotional and behaviour problems in a sample of PHIV+ children compared to well-matched HIV-negative controls. There were four main findings. First, this study found that $14 \%$ of PHIV + children had emotional and behavioural problems using the CBCL total problems clinical cut-off. Second, demographic and contextual variables were comparable between the two groups except cognitive performance scores which were significantly lower in the PHIV+ group. Third, caregiver depression predicted greater total problems in both groups; this correlation was stronger in the control group. Fourth, PHIV+ children on ART 
had fewer emotional and behavioural problems than PHIV+ on ART with encephalopathy and ART naïve PHIV+ children.

The rate of emotional and behavioural problems in our study is lower than other LMIC studies. It is difficult to draw comparisons across studies with different methodologies and this lower rate may reflect more rigorous methodology and clearly defined measure cut-offs rather than true lower prevalence. Two other African studies have used the CBCL (Nöthling et al., 2013; Tadesse et al., 2012). Tadesse's Ethiopian study reported rates of 39\% of overall emotional and behavioural problems in 6-14 year old HIV-infected children on ART, however it is not clear from the methodology how this percentage was calculated (Tadesse et al., 2012). In their sample $(\mathrm{N}=318)$ $54.1 \%$ of children had a history of hospital admission for more than 5 days, $3.5 \%$ due to seizures, whereas our study excluded children with serious medical comorbidities and previous central nervous system conditions. Children with serious medical illnesses and seizure disorders would be at greater risk for behaviour problems. Tadesse's study used the United Stated reference norm group for CBCL scoring while our scoring was based on multicultural norms which may also explain the higher reported rates in their sample. Nöthling's longitudinal South African study of 70 mother-child dyads infected with HIV found rates $44 \%$ of problem behaviours using the clinical cut-off on the CBCL preschool version in a sample of younger PHIV+ children assessed at 42 months (Nöthling et al., 2013). These participants were also recruited from CHCs in South Africa however the sample size was smaller and children younger than the sample in our study making comparisons across these studies difficult. Parents of older children may be used to certain behaviours and therefore less likely to report them as problematic. In our sample HIV-infection in children predicted greater problems which is in keeping with most LMIC studies that have reported higher rates of emotional and behaviour problems in HIV-positive youth when compared to HIV-negative controls (Grover et al., 2007; Louthrenoo et al., 2014; Menon et al., 2007; Puthanakit et al., 2013).

The finding that cognitive performance scores were significantly lower in the PHIV + group is not surprising as the cognitive domains selected for the score were chosen because they are known to be affected in PHIV+ youth (Laughton et al., 2013). Despite being significantly lower, cognitive 
performance scores did not predict greater emotional and behavioural problems as has been shown in other studies (Malee et al., 2011; Nozyce et al., 2006; Puthanakit et al., 2013). It is possible that behavioural problems as a result of cognitive difficulties, particularly externalizing behaviours, may only manifest in older children. The average age of children in our sample was 10 years and there was trend-level evidence for greater problems in older children. The CBCL relies on subjective reporting by caregivers and caregivers of children with cognitive problems may have become used to certain behaviours and therefore not have reported them.

Caregiver depression has been correlated with greater emotional and behavioural problems in other studies of PHIV+ youth (Mellins \& Malee, 2014) and youth from other populations (Billings \& Moos, 1986; Cummings, Keller, \& Davies, 2005; Luoma et al., 2001). The correlation between caregiver depression and behaviour problems was less strong in the PHIV+ group which may be because of the impact of other HIV related factors such as child nadir CD4 count, child age of ART initiation, parental loss and caregiver HIV status that were not measured in this study. The rates of caregiver depression in both groups were higher than life time prevalence rates of depression reported in South Africa (9.7\%) (Tomlinson, Grimsrud, Stein, Williams, \& Myer, 2009). All participants in our study came from communities with limited resources and multiple psychosocial stressors which may explain the higher rates of depression. In our sample greater depression was correlated with lower perceived resources. Nöthling et al's South African study reported similarly high caregiver depression rates of 50\% in a comparable community sample (Nöthling et al., 2013). The demographic characteristics of caregivers in our sample may also account for the high rates of depression. The majority of caregivers were female (97\%), $60 \%$ were single, widowed or divorced and $65 \%$ were unemployed. These are all factors known to increase vulnerability to depression (McKee-Ryan, Song, Wanberg, \& Kinicki, 2005; Weissman et al., 1996). The demographic risk factors and stressors facing these caregivers appear to put them at risk of depression whether or not they are caring for an HIV-infected child. LMIC studies have shown that disturbed family environment, living with a caregiver or in foster care, parental loss and low income are associated with greater emotional and behavioural problems in PHIV+ children (Grover et al., 2007; 
Louthrenoo et al., 2014; Tadesse et al., 2012). Apart from caregiver depression none of the other contextual variables measured in our study were correlated with greater problem behaviours in the regression analysis. Lack of resources appear to mediate the effect on problem behaviour through higher rates of caregiver depression. Of all the many stressors faced by HIV-affected families and families living in difficult socio-economic environments this study highlights the importance of caregiver mental health. Depression can be screened for and treated and this may help to reduce child behaviour problems.

Of the biological variables, PHIV+ children on ART had fewer problems than PHIV+ on ART with encephalopathy and ART naïve PHIV+ children. This finding is interesting because children who have not required ART may be perceived as being healthier despite evidence of cognitive dysfunction and virus mediated neurological damage (Hoare et al., 2012). Early initiation of ART is now well supported by studies that show improved clinical and immunological outcomes as well as improved quality of life outcomes in children started earlier on ART (Bunupuradah et al., 2013; Cotton et al., 2013). There was no significant difference in perceived access to resources and social support between the PHIV+ subgroups. There was trend-level evidence $(\mathrm{p}<0.1)$ for greater perceived resources in the encephalopathy group which may be because these children were accessing medical care at tertiary level hospitals.

This study is not without limitations. The CBCL relies on subjective reporting of problem behaviours and caregivers may have under or over reported behaviours. The HIV-negative status of the control group children was not confirmed using HIV testing. Caregiver HIV status and rates of parental loss were not determined. These are two important variables that should be explored in future studies considering the correlation between caregiver depression and child emotional and behavioural problems. Other important child HIV-related variables such as nadir CD4 count and age of ART initiation were not measured. The sample size was relatively small which may have limited the power of some of the statistical findings. As this is a cross sectional study it is difficult to determine the direction of the associations. 


\section{Conclusion}

This study shows that HIV-infection in children predicts greater emotional and behavioural problems when compared to matched HIV-negative controls. In both groups caregiver depression was significantly associated with emotional and behavioural problems, although this association was stronger in the control group. This highlights the need for adequate screening of depression in the caregivers of HIV-infected children as well as caregivers of all children presenting with problem behaviours. Treating caregiver depression may help reduce emotional and behavioural problems in children in our communities. 


\section{References:}

Achenbach, T. M., \& Ruffle, T. M. (2000). The Child Behavior Checklist and related forms for assessing behavioral/emotional problems and competencies. Pediatrics in Review / American Academy of Pediatrics, 21(8), 265-271.

AIDS, J. U. N. P. O. H. (2012). Global report: UNAIDS report on the global AIDS epidemic: 2012.

Albores-Gallo, L., Lara-Muñoz, C., Esperón-Vargas, C., Cárdenas Zetina, J. A., Pérez Soriano, A. M., \& Villanueva Colin, G. (2007). Validity and reability of the CBCL/6-18. Includes DSM scales. Actas Españolas De Psiquiatría, 35(6), 393-399.

Ananworanich, J., Jupimai, T., Mekmullica, J., Sosothikul, D., \& Pancharoen, C. (2008). Behavioral and emotional problems in Thai children with HIV infection compared to children with and without other chronic diseases. Journal of the International Association of Physicians in AIDS Care (Chicago, Ill. : 2002), 7(1), 52-53. doi:10.1177/1545109707305173

Bachanas, P. J., Kullgren, K. A., Schwartz, K. S., Lanier, B., McDaniel, J. S., Smith, J., \& Nesheim, S. (2001). Predictors of psychological adjustment in school-age children infected with HIV. Journal of Pediatric Psychology, 26(6), 343-352.

Billings, A. G., \& Moos, R. H. (1986). Children of parents with unipolar depression: a controlled 1year follow-up. Journal of Abnormal Child Psychology, 14(1), 149-166.

Bomba, M., Nacinovich, R., Oggiano, S., Cassani, M., Baushi, L., Bertulli, C., et al. (2010). Poor health-related quality of life and abnormal psychosocial adjustment in Italian children with perinatal HIV infection receiving highly active antiretroviral treatment. Dx.Doi.org, 22(7), 85865. doi:10.1080/09540120903483018

Boyes, M. E., \& Cluver, L. D. (2014). Relationships Between Familial HIV/AIDS and Symptoms of Anxiety and Depression: The Mediating Effect of Bullying Victimization in a Prospective Sample of South African Children and Adolescents. Journal of Youth and Adolescence, 1-13. doi:10.1007/s10964-014-0146-3

Brannan, A. M., Manteuffel, B., Holden, E. W., \& Heflinger, C. A. (2006). Use of the family resource scale in children's mental health: reliability and validity among economically diverse samples. Administration and Policy in Mental Health, 33(2), 182-197. doi:10.1007/s10488006-0032-8

Bunupuradah, T., Kosalaraksa, P., Vibol, U., Hansudewechakul, R., Sophonphan, J., Kanjanavanit, S., et al. (2013). Impact of antiretroviral therapy on quality of life in HIV-infected Southeast Asian children in the PREDICT study. AIDS Patient Care and STDs, 27(11), 596-603. doi:10.1089/apc.2013.0203

Cluver, L. D., Gardner, F., \& Operario, D. (2008). Effects of stigma on the mental health of adolescents orphaned by AIDS. The Journal of Adolescent Health: Official Publication of the Society for Adolescent Medicine, 42(4), 410-417. doi:10.1016/j.jadohealth.2007.09.022

Cluver, L., Gardner, F., \& Operario, D. (2007). Psychological distress amongst AIDS-orphaned children in urban South Africa. Journal of Child Psychology and Psychiatry, and Allied Disciplines, 48(8), 755-763. doi:10.1111/j.1469-7610.2007.01757.x

Cotton, M. F., Violari, A., Otwombe, K., Panchia, R., Dobbels, E., Rabie, H., et al. (2013). Early time-limited antiretroviral therapy versus deferred therapy in South African infants infected with HIV: results from the children with HIV early antiretroviral (CHER) randomised trial. The Lancet, 382(9904), 1555-1563. doi:10.1016/S0140-6736(13)61409-9

Cummings, E. M., Keller, P. S., \& Davies, P. T. (2005). Towards a family process model of maternal and paternal depressive symptoms: exploring multiple relations with child and family functioning. Journal of Child Psychology and Psychiatry, and Allied Disciplines, 46(5), 479489. doi:10.1111/j.1469-7610.2004.00368.x

Dunst, C. J., \& Leet, H. E. (1987). Measuring the adequacy of resources in households with young children. Child: Care, Health and Development, 13(2), 111-125.

Dunst, C. J., Trivette, C. M., \& Cross, A. H. (1986). Mediating influences of social support: personal, family, and child outcomes. American Journal of Mental Deficiency, 90(4), 403-417.

Gadow, K. D., Chernoff, M., Williams, P. L., Brouwers, P., Morse, E., Heston, J., et al. (2010). Cooccuring psychiatric symptoms in children perinatally infected with HIV and peer comparison 
sample. Journal of Developmental and Behavioral Pediatrics : JDBP, 31(2), 116-128. doi:10.1097/DBP.0b013e3181cdaa20

Grover, G., Pensi, T., \& Banerjee, T. (2007). Behavioural disorders in 6-11-year-old, HIV-infected Indian children. Annals of Tropical Paediatrics, 27(3), 215-224. doi:10.1179/146532807X220334

Hanley, B., Tassé, M. J., Aman, M. G., \& Pace, P. (1998). Psychometric Properties of the Family Support Scale with Head Start Families. Journal of Child and Family Studies, 7(1), 69-77. doi:10.1023/A:1022912130180

Hoare, J., Fouche, J.-P., Spottiswoode, B., Donald, K., Philipps, N., Bezuidenhout, H., et al. (2012). A diffusion tensor imaging and neurocognitive study of HIV-positive children who are HAART-naïve "slow progressors." Journal of Neurovirology, 18(3), 205-212. doi:10.1007/s13365-012-0099-9

Kang, E., Mellins, C. A., Dolezal, C., Elkington, K. S., \& Abrams, E. J. (2011). Disadvantaged neighborhood influences on depression and anxiety in youth with perinatally acquired human immunodeficiency virus: how life stressors matter. Journal of Community Psychology, 39(8), 956-971. doi:10.1002/jcop.20483

Landon, M., Joalida, S., Le, R. L., Siraaj, P., J, S. D., \& Soraya, S. (2008). Common Mental Disorders among HIV-Infected Individuals in South Africa: Prevalence, Predictors, and Validation of Brief Psychiatric Rating Scales. Dx.Doi.org, 22(2), 147-58. doi:10.1089/apc.2007.0102

Laughton, B., Cornell, M., Boivin, M., \& Van Rie, A. (2013). Neurodevelopment in perinatally HIV-infected children: a concern for adolescence. Journal of the International AIDS Society, 16(1), 18603. doi:10.7448/IAS.16.1.18603

Lee, B., Chhabra, M., \& Oberdorfer, P. (2011). Depression among Vertically HIV-Infected Adolescents in Northern Thailand. Journal of the International Association of Providers of AIDS Care (JIAPAC), 10(2), 89-96. doi:10.1177/1545109710397892

Louthrenoo, O., Oberdorfer, P., \& Sirisanthana, V. (2014). Psychosocial functioning in adolescents with perinatal HIV infection receiving highly active antiretroviral therapy. Journal of the International Association of Providers of AIDS Care (JIAPAC), 13(2), 178-183. doi:10.1177/2325957413488171

Lowenthal, E., Lawler, K., Harari, N., Moamogwe, L., Masunge, J., Masedi, M., et al. (2012). Rapid psychosocial function screening test identified treatment failure in HIV+ African youth. AIDS Care, 24(6), 722-727. doi:10.1080/09540121.2011.644233

Luoma, I., Tamminen, T., Kaukonen, P., Laippala, P., Puura, K., Salmelin, R., \& Almqvist, F. (2001). Longitudinal study of maternal depressive symptoms and child well-being. Journal of the American Academy of Child and Adolescent Psychiatry, 40(12), 1367-1374. doi:10.1097/00004583-200112000-00006

Malee, K. M., Tassiopoulos, K., Huo, Y., Siberry, G., Williams, P. L., Hazra, R., et al. (2011). Mental health functioning among children and adolescents with perinatal HIV infection and perinatal HIV exposure. Dx.Doi.org, 23(12), 1533-44. doi:10.1080/09540121.2011.575120

McKee-Ryan, F., Song, Z., Wanberg, C. R., \& Kinicki, A. J. (2005). Psychological and physical well-being during unemployment: a meta-analytic study. The Journal of Applied Psychology, 90(1), 53-76. doi:10.1037/0021-9010.90.1.53

Mellins, C. A., \& Malee, K. M. (2014). Understanding the mental health of youth living with perinatal HIV infection: lessons learned and current challenges. Journal of the International AIDS Society, 16(1), 18593. doi:10.7448/ias.16.1.18593

Mellins, C. A., Brackis Cott, E., Leu, C. S., Elkington, K. S., Dolezal, C., Wiznia, A., et al. (2009).

Rates and types of psychiatric disorders in perinatally human immunodeficiency virus-infected youth and seroreverters. Journal of Child Psychology and Psychiatry, 50(9), 1131-1138. doi:10.1111/j.1469-7610.2009.02069.x

Mellins, C. A., Tassiopoulos, K., Malee, K., Moscicki, A.-B., Patton, D., Smith, R., et al. (2011). Behavioral Health Risks in Perinatally HIV-Exposed Youth: Co-Occurrence of Sexual and Drug Use Behavior, Mental Health Problems, and Nonadherence to Antiretroviral Treatment. Dx.Doi.org, 25(7), 413-22. doi:10.1089/apc.2011.0025 
Menon, A., Glazebrook, C., Campain, N., \& Ngoma, M. (2007). Mental health and disclosure of HIV status in Zambian adolescents with HIV infection: implications for peer-support programs. Journal of Acquired Immune Deficiency Syndromes (1999), 46(3), 349-354. doi:10.1097/QAI.0b013e3181565df0

Musisi, S., \& Kinyanda, E. (2009). Emotional and behavioural disorders in HIV seropositive adolescents in urban Uganda. East African Medical Journal, 86(1), 16-24.

Nozyce, M. L., Lee, S. S., Wiznia, A., Nachman, S., Mofenson, L. M., Smith, M. E., et al. (2006). A Behavioral and Cognitive Profile of Clinically Stable HIV-Infected Children. Pediatrics, 117(3), 763-770. doi:10.1542/peds.2005-0451

Nöthling, J., Martin, C. L., Laughton, B., Cotton, M. F., \& Seedat, S. (2013). Maternal posttraumatic stress disorder, depression and alcohol dependence and child behaviour outcomes in mother-child dyads infected with HIV: a longitudinal study. BMJ Open, 3(12), e003638e003638. doi:10.1136/bmjopen-2013-003638

Oguz, A., Kurul, S., Dirik, E., \& Eylül, D. (2002). Relationship of Epilepsy-Related Factors to Anxiety and Depression Scores in Epileptic Children. Journal of Child Neurology, 17(1), 37 40. doi:10.1177/088307380201700109

Petersen, I., Bhana, A., Myeza, N., Alicea, S., John, S., Holst, H., et al. (2010). Psychosocial challenges and protective influences for socio-emotional coping of HIV+ adolescents in South Africa: a qualitative investigation, 22(8), 970-8. doi:10.1080/09540121003623693

Puthanakit, T., Ananworanich, J., Vonthanak, S., Kosalaraksa, P., Hansudewechakul, R., van der Lugt, J., et al. (2013). Cognitive function and neurodevelopmental outcomes in HIV-infected Children older than 1 year of age randomized to early versus deferred antiretroviral therapy: the PREDICT neurodevelopmental study. The Pediatric Infectious Disease Journal, 32(5), 501508. doi:10.1097/INF.0b013e31827fb19d

Radloff, L. S. (1977). The CES-D Scale A Self-Report Depression Scale for Research in the General Population. Applied Psychological Measurement, 1(3), 385-401. doi:10.1177/014662167700100306

Singh, D., Sunpath, H., John, S., Eastham, L., \& Gouden, R. (2008). The utility of a rapid screening tool for depression and HIV dementia amongst patients with low CD4 counts- a preliminary report. African Journal of Psychiatry, 11(4), 282-286.

Tadesse, A. W., Tsehay, Y. B., Belaineh, B. G., \& Alemu, Y. B. (2012). Behavioral and emotional problems among children aged 6-14 years on highly active antiretroviral therapy in Addis Ababa: A cross-sectional study. Dx.Doi.org, 24(11), 1359-67. doi:10.1080/09540121.2011.650677

Tomlinson, M., Grimsrud, A. T., Stein, D. J., Williams, D. R., \& Myer, L. (2009). The epidemiology of major depression in South Africa: results from the South African stress and health study. South African Medical Journal = Suid-Afrikaanse Tydskrif Vir Geneeskunde, 99(5 Pt 2), 367373.

Weissman, M. M., Bland, R. C., Canino, G. J., Faravelli, C., Greenwald, S., Hwu, H. G., et al. (1996). Cross-national epidemiology of major depression and bipolar disorder. Jama, 276(4), 293-299.

World Health Organization. (2014). Health for the world's adolescents: a second chance in the second decade: summary. 
Tables

Table 1: Neuropsychological Domains Selected for the Cognitive Performance Score and the Tests from the Neuropsychological Test Battery Used for the Z-score Calculation

\begin{tabular}{|l|l|}
\hline Cognitive Domain & Test \\
\hline Processing speed & WISC Processing Speed Index (Wechsler, 2004) \\
\hline Attention & WISC, TEA-Ch (Manly et al., 2001) \\
\hline Visual spatial ability & WASI block design (Wechsler, 1999), Rey \\
& Complex Figure (J. E. Meyers \& Meyers, 1995) \\
\hline Visual memory & \begin{tabular}{l} 
Rey Complex Figure recall and delay \\
\hline Executive functioning
\end{tabular} \\
& $\begin{array}{l}\text { Nepsy inhibition (Korkman, Kirk, \& Kemp, } \\
\text { 2007), Nepsy switching, Nepsy naming, } \\
\text { Category and Phonetic Fluency, WASI Matrix } \\
\text { Reasoning }\end{array}$ \\
\hline
\end{tabular}


Table 2: Demographic, Psychological, Contextual and Biological Variables of Children Perinatally Infected with HIV (PHIV+) and HIV-negative Controls

\begin{tabular}{|c|c|c|c|c|}
\hline Variable $^{1}$ & $\begin{array}{l}\text { PHIV+ Children } \\
\mathbf{N}=78\end{array}$ & $\begin{array}{l}\text { HIV-negative Controls } \\
\mathbf{N}=30\end{array}$ & $\begin{array}{l}\text { Statistical } \\
\text { Test }^{2}\end{array}$ & $P$ value \\
\hline Age in years & $10.26(2.41)$ & $10.15(2.16)$ & $\mathrm{t}=-0.22$ & 0.83 \\
\hline $\begin{array}{l}\text { Gender } \\
(\% \text { female })\end{array}$ & 52.6 & 50 & $\chi=0,06$ & 0.81 \\
\hline $\begin{array}{l}\text { Cognitive } \\
\text { Performance } \\
\text { Score }\end{array}$ & $-0.41(0.52)$ & $0.01(0.55)$ & $\mathrm{t}=3.52$ & $<0.001 *$ \\
\hline $\begin{array}{l}\text { Caregiver } \\
\text { Relationship } \\
\text { (\% biological } \\
\text { parent })^{3}\end{array}$ & 58.9 & 70 & $\chi=1.12$ & 0.29 \\
\hline $\begin{array}{l}\text { Overcrowding } \\
\text { (people per } \\
\text { room) }\end{array}$ & $2.55(1.62)$ & $2.63(1.59)$ & $\mathrm{z}=0.51$ & 0.62 \\
\hline FRS & 74.35 (19.71) & $70.63(16.73)$ & $\mathrm{t}=-0.98$ & 0.33 \\
\hline FSS & $33.01(14.03)$ & $33.93(16.52)$ & $\mathrm{z}=-0.10$ & 0.92 \\
\hline CESD & $15.81(11.15)$ & $17.33(10.34)$ & $\mathrm{z}=0.10$ & 0.37 \\
\hline $\begin{array}{l}\mathrm{VL}^{4} \\
(\% \text { detectable })\end{array}$ & 24.2 & & & \\
\hline CD4 count ${ }^{5}$ & $806(573-1243)$ & & & \\
\hline
\end{tabular}

FRS= Family Resource Scale, FSS= Family Support Scale, CESD $=$ Center for Epidemiologic Studies- Depression Scale, $\mathrm{VL}=$ viral load

\footnotetext{
${ }^{1}$ Summary statistics for continuous variables reported as means, with standard deviation in parentheses

${ }^{2} \mathrm{z}=\mathrm{z}$-score from implementation of Mann-Whitney test in $\mathrm{R}$ coin package; $\mathrm{t}=\mathrm{t}$-score from independent t-test, $\chi=$ statistical output of chi-squared test

${ }^{3}$ Other primary caregivers identified were grandmothers, aunts, stepmothers, adoptive mothers

${ }^{4}$ Total sample $=66$

${ }^{5}$ Total sample $=73$; reported as median with interquartile range in parentheses
} 
Table 3: Demographic, Psychological, Contextual and Biological Variables of Children Perinatally Infected with HIV (PHIV+) Compared by Subgroup: ART Naïve Children, Children on ART and Children on ART with Encephalopathy

\begin{tabular}{|c|c|c|c|c|c|}
\hline Variable $^{1}$ & $\begin{array}{l}\text { ART Naïve } \\
\mathrm{N}=14\end{array}$ & $\begin{array}{l}\text { ART } \\
N=46\end{array}$ & $\begin{array}{l}\text { Encephalopthy } \\
\mathrm{N}=18\end{array}$ & Statistical Test $^{2}$ & P-value \\
\hline Age in years & $9.48(1.77)$ & $10.84(2.56)$ & $9.37(2.06)$ & $F=3.516$ & $\mathrm{p}=0.04^{*}$ \\
\hline $\begin{array}{l}\text { Gender(\% } \\
\text { female) }\end{array}$ & $71 \%$ & $48 \%$ & $50 \%$ & $\begin{array}{l}\mathrm{df}=2,75 \\
\chi=2.46 \\
\mathrm{df}=2\end{array}$ & $\mathrm{p}=0.29$ \\
\hline $\begin{array}{l}\text { Cognitive } \\
\text { Performance } \\
\text { Score }\end{array}$ & $-0.3(0.54)$ & $-0.4(0.49)$ & $-0.5(0.57)$ & $\begin{array}{l}F=0.62 \\
d f=2.75\end{array}$ & $\mathrm{p}=0.54$ \\
\hline $\begin{array}{l}\text { Caregiver } \\
\text { Relationship } \\
(\% \text { biological } \\
\text { parent })\end{array}$ & $71 \%$ & $61 \%$ & $44 \%$ & $\begin{array}{l}\chi=3.73 \\
\mathrm{df}=3\end{array}$ & $\mathrm{p}=0.29$ \\
\hline $\begin{array}{l}\text { Overcrowding } \\
\text { (people per room) }\end{array}$ & $2.73(1.98)$ & $2.64(1.44)$ & $2.16(1.79)$ & $\begin{array}{l}\chi=3.93 \\
\mathrm{df}=2\end{array}$ & $\mathrm{p}=0.14$ \\
\hline FRS & $73.15(23.73)$ & $71.04(15.85)$ & $83.67(23.49)$ & $\begin{array}{l}F=2.81 \\
d f=2.74\end{array}$ & $\mathrm{p}=0.07$ \\
\hline FSS & $36.08(20.46)$ & $33.3(12.19)$ & $30.06(13.2)$ & $\begin{array}{l}F=0.72 \\
d f=2.74\end{array}$ & $\mathrm{p}=0.49$ \\
\hline CESD & $17.43(15.27)$ & $15.09(9.67)$ & $16.39(11.53)$ & $\begin{array}{l}F=0.26 \\
d f=2.75\end{array}$ & $p=0.77$ \\
\hline $\begin{array}{l}\mathrm{VL}^{3} \\
(\% \text { detectable })\end{array}$ & $\begin{array}{l}60 \% \\
567(521-763)\end{array}$ & $\begin{array}{l}21 \% \\
846 \\
(637-1024)\end{array}$ & $\begin{array}{l}11 \% \\
1216 \\
(641-1087)\end{array}$ & $\begin{array}{l}\chi=8.863 \\
\mathrm{df}=2\end{array}$ & $\mathrm{p}=0.01^{*}$ \\
\hline CD4 count ${ }^{4}$ & $568(521-730)$ & $\begin{array}{l}846 \\
(673-1024)\end{array}$ & $\begin{array}{l}1216 \\
(641-1333)\end{array}$ & $\begin{array}{l}\chi=8.048 \\
\mathrm{df}=2\end{array}$ & $\mathrm{p}=0.02 *$ \\
\hline
\end{tabular}

FRS $=$ Family Resource Scale, FSS= Family Support Scale, CESD $=$ Center for Epidemiologic Studies- Depression Scale, $\mathrm{VL}=$ viral load

\footnotetext{
${ }^{1}$ Summary statistics for continuous variables reported as means, with standard deviation in parentheses

${ }^{2}$ Statistical tests reported as ANOVAS for continuous variables, Chi Squared tests for categorical variables; $\mathrm{F}=\mathrm{F}$ statistic, $\chi=$ statistical output of chi-squared test

${ }^{3}$ Viral load reported as $\%$ detectable and median with interquartile range in parentheses

${ }^{4} \mathrm{CD} 4$ count reported as median with interquartile range in parentheses
} 
Table 4: Correlation Matrix Indicating the Relationship Between Contextual Variables

\begin{tabular}{|lccc|}
\hline Variable $^{1}$ & CESD & FRS & FSS \\
\hline FRS $^{2}$ & $-0.25(0.01) *$ & & \\
FSS $^{2}$ & $0.01(0.93)$ & $0.22(0.02)^{*}$ & \\
$\begin{array}{l}\text { Household } \\
\text { Crowding }\end{array}$ & $-0.12(0.23)$ & $-0.06(0.55)$ & $-0.13(0.20)$ \\
\hline
\end{tabular}

$\mathrm{CESD}=$ Center for Epidemiological Studies-Depression Scale, FRS $=$ Family Resources Scale, FSS= Family Support Scale

\footnotetext{
${ }^{1}$ Reported as Pearsons correlation coefficients with probability value in parentheses

${ }^{2}$ One data point is missing for FRS and FSS
} 
Table 5: Prevalence of Internalizing, Externalizing and Total Problem Scores at the Clinical (>65) and Borderline (>60) Cut-off Ranges on the Child Behaviour Checklist (CBCL) of Children Perinatally Infected with HIV (PHIV+) and HIV-negative Controls

\begin{tabular}{|lllll|}
\hline CBCL Scales & PHIV+Children & & \multicolumn{2}{l|}{ HIV-negative Children } \\
& Clinical range & Borderline range & Clinical Range & Borderline Range \\
\hline $\begin{array}{l}\text { Internalizing } \\
\text { Problems }\end{array}$ & $12 \%(\mathrm{n}=9)$ & $33 \%(\mathrm{n}=25)$ & $10 \%(\mathrm{n}=3)$ & $37 \%(\mathrm{n}=11)$ \\
$\begin{array}{l}\text { Externalizing } \\
\text { Problems }\end{array}$ & $8 \%(\mathrm{n}=6)$ & $22 \%(\mathrm{n}=17)$ & $20 \%(\mathrm{n}=6)$ & $23 \%(\mathrm{n}=7)$ \\
Total Problems & $14 \%(\mathrm{n}=11)$ & $19 \%(\mathrm{n}=21)$ & $17 \%(\mathrm{n}=5)$ & $30 \%(\mathrm{n}=9)$ \\
\hline
\end{tabular}


Table 6: Child Behaviour Checklist (CBCL) Results in Children Perinatally Infected with HIV (PHIV+) and HIV-negative Controls

\begin{tabular}{|c|c|c|c|c|c|c|c|c|c|c|c|c|}
\hline \multirow[t]{2}{*}{ CBCL Scales } & \multicolumn{4}{|c|}{ PHIV+ Children } & \multicolumn{6}{|c|}{ HIV-negative Controls } & \multicolumn{2}{|c|}{ Statistical Test } \\
\hline & $\mathbf{n}$ & Mean & SD & Median & Range & $\mathbf{n}$ & Mean & SD & Median & Range & z score & p value \\
\hline \multicolumn{13}{|l|}{ Internalizing Problems } \\
\hline Anxious/Depressed & 78 & 56.22 & 7.05 & 54 & $50-88$ & 30 & 57.83 & 7.9 & 56 & $50-88$ & 1.48 & 0.14 \\
\hline Withdrawn/Depressed & 78 & 56.9 & 7.46 & 55 & $50-88$ & 30 & 55.77 & 6.03 & 54 & $50-66$ & -0.60 & 0.55 \\
\hline $\begin{array}{l}\text { Somatic Complaints } \\
\text { Other problems }\end{array}$ & 78 & 59.88 & 8.59 & 61 & $50-86$ & 30 & 57.57 & 6.91 & 57 & $50-76$ & -1.24 & 0.22 \\
\hline Social Problems & 78 & 56.59 & 6.17 & 54 & $50-75$ & 30 & 55.7 & 5.79 & 54 & $50-75$ & -0.77 & 0.44 \\
\hline Thought Problems & 78 & 55.88 & 7.62 & 54 & $50-82$ & 30 & 55.23 & 7.27 & 51 & $50-74$ & -0.44 & 0.66 \\
\hline Attention Problems & 78 & 58.24 & 8.45 & 55 & $50-100$ & 30 & 56.57 & 9.17 & 53 & $50-88$ & -1.59 & 0.11 \\
\hline \multicolumn{13}{|c|}{ Externalizing Problems } \\
\hline \multicolumn{13}{|l|}{ Rule-Breaking } \\
\hline Behaviour & 78 & 55.65 & 5.74 & 54.5 & $50-76$ & 30 & 55.7 & 7.39 & 52 & $50-76$ & -0.73 & 0.46 \\
\hline Aggressive Behaviour & 78 & 57.96 & 7.84 & 57 & $50-92$ & 30 & 58.3 & 10.78 & 53.5 & $50-93$ & -0.90 & 0.37 \\
\hline \multicolumn{13}{|l|}{ DSM Orientated Scales } \\
\hline Affective Problems & 78 & 59.82 & 8.15 & 60 & $50-86$ & 30 & 59.4 & 7.91 & 58.5 & $50-76$ & -0.14 & 0.89 \\
\hline Anxiety Problems & 78 & 54.51 & 6.43 & 51 & $50-75$ & 30 & 55.9 & 6.89 & 54 & $50-78$ & 0.92 & 0.36 \\
\hline Somatic Problems & 78 & 61.1 & 8.61 & 61 & $50-90$ & 30 & 57.73 & 7.83 & 58 & $50-77$ & -1.87 & $0.06^{*}$ \\
\hline \multicolumn{13}{|l|}{ Attention } \\
\hline \multicolumn{13}{|l|}{ Deficit/Hyperactivity } \\
\hline \multirow{2}{*}{\multicolumn{13}{|c|}{ Oppositional Defiant }} \\
\hline & & & & & & & & & & & & \\
\hline Problems & 78 & 55.1 & 6.45 & 52 & $50-80$ & 30 & 55.3 & 7.23 & 51.5 & $50-73$ & -0.85 & 0.39 \\
\hline Conduct Problems & 78 & 57.5 & 7.25 & 56 & $50-81$ & 30 & 57.3 & 8.42 & 54 & $50-78$ & -0.73 & 0.46 \\
\hline \multicolumn{10}{|l|}{ Internalizing } & $33-83$ & -0.12 & 0.91 \\
\hline Externalizing & & & & & & 30 & & & & & & \\
\hline Problems & 78 & 56.19 & 7.54 & 56 & $40-78$ & & 54.97 & 11.06 & 52 & $34-78$ & -1.18 & 0.24 \\
\hline Total Problems & 78 & $\mathbf{5 7 . 5 1}$ & 7.78 & 57 & 40-79 & 30 & 55.5 & 10.77 & 54 & $25-77$ & -1.22 & 0.22 \\
\hline
\end{tabular}
$*=\mathrm{p}<0.1$ 
Table 7: Estimates for the Final Model of Total Problems

\begin{tabular}{|l|l|l|l|l|}
\hline & Coeff & Std Error & T & P Value \\
\hline Model intercept & 44.91 & 2.92 & 15.37 & $<0.001$ \\
\hline HIV status & 8.40 & 3.07 & 2.74 & 0.01 \\
\hline Child gender & -2.62 & 1.49 & -1.76 & 0.08 \\
\hline Child age & 2.88 & 1.49 & 1.93 & 0.06 \\
\hline Caregiver depression & 0.60 & 0.13 & 4.53 & $<0.001$ \\
\hline HIV status - Depression interaction & -0.34 & 0.15 & -2.20 & 0.03 \\
\hline
\end{tabular}


Figure 1: Scatter Plot of Interaction of HIV Status, Caregiver Depression and CBCL Total Problem Scores

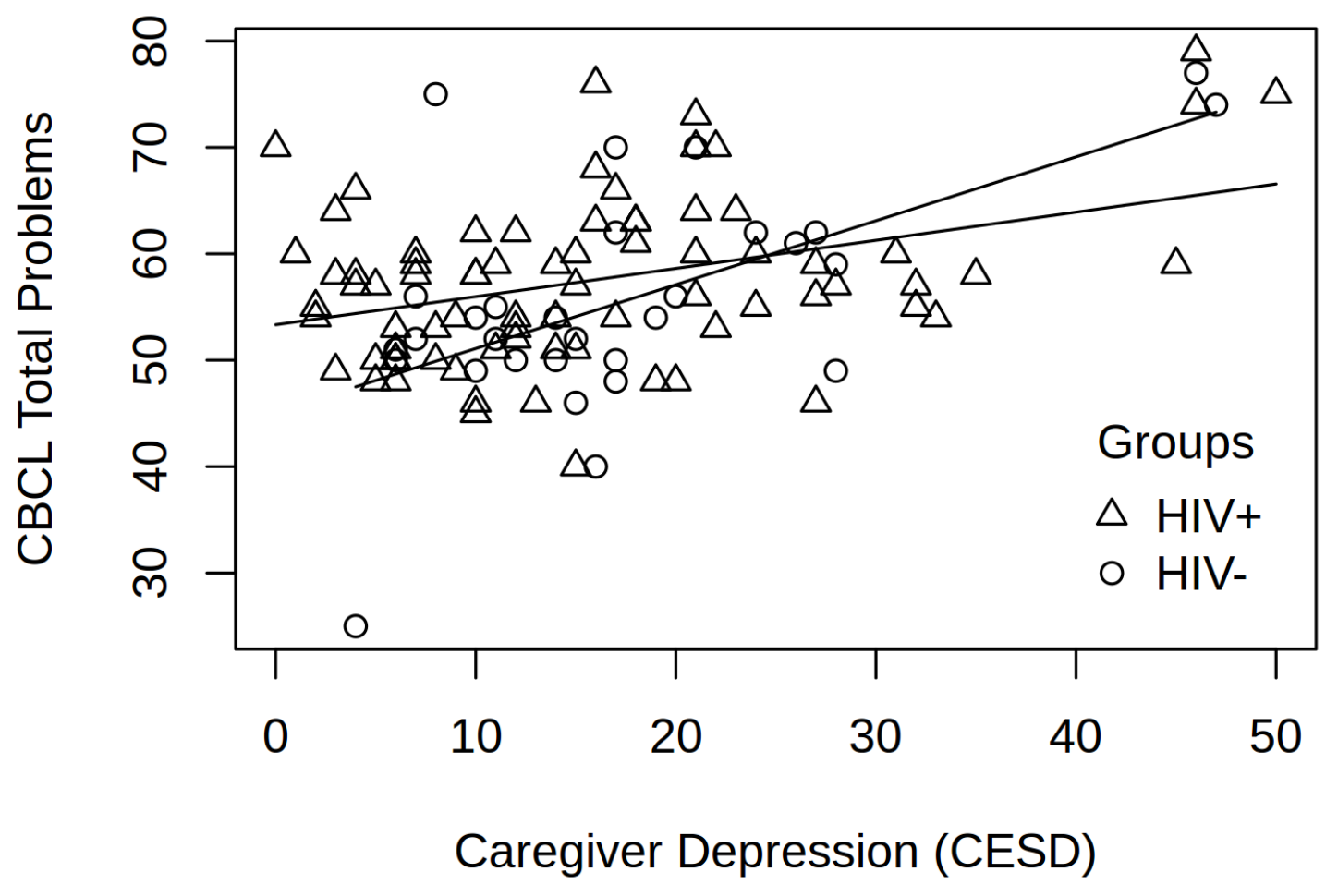


Appendix A Ethics approval letter

UNIVERSITY OF CAPE TOWN

Faculty of Health Sciences

Human Research Ethics Committee

\author{
Room E52-24 Old Main Building \\ Groote Schuur Hospital \\ Observatory 7925 \\ Telephone [021] 4066338 • Facsimile [021] 4066411 \\ Email: shuretta thomas@uct ac $z$ \\ Website: www.health.uct.ac.za/research/humanethics/forms
}

04 December 2013

HREC REF: 701/2013

Dr K Louw

c/o Dr J Hoare

Psychiatry \& Mental Health

Room 65, J-block

GSH

Dear Dr Louw

PROJECT TITLE: CORRELATES OF EMOTIONAL AND BEHAVIOURAL PROBLEMS IN CHILDREN WITH PERINATALLY ACQUIRED HIV IN CAPE TOWN SOUTH AFRICA

Thank you for your letter to the Faculty of Health Sciences Human Research Ethics Committee dated $29^{\text {th }}$ November 2013.

It is a pleasure to inform you that the HREC has formally approved the above-mentioned study.

Approval is granted for one year until the $30^{\text {th }}$ December 2014

Please submit a progress form, using the standardised Annual Report Form if the study continues beyond the approval period. Please submit a Standard Closure form if the study is completed within the approval period. (Forms can be found on our website: www.health.uct.ac.za/research/humanethics/forms)

Please note that the ongoing ethical conduct of the study remains the responsibility of the principal investigator.

Please quote the HREC reference no in all your correspondence.

Yours sincerely

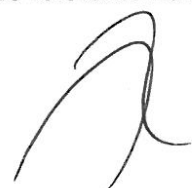

\title{
PROFESSOR M BLOCKMAN
}

\section{CHAIRPERSON, FHS HUMAN ETHICS}

Federal Wide Assurance Number: FWA00001637.

Institutional Review Board (IRB) number: IRB00001938

This serves to confirm that the University of Cape Town Human Research Ethics Committee complies to the Ethics Standards for Clinical Research with a new drug in patients, based on the Medical

Research Council (MRC-SA), Food and Drug Administration (FDA-USA), International Convention on Harmonisation Good Clinical Practice (ICH GCP) and Declaration of Helsinki guidelines.

The Human Research Ethics Committee granting this approval is in compliance with the ICH Harmonised Tripartite Guidelines E6: Note for Guidance on Good Clinical Practice (CPMP/ICH/135/95) and FDA Code Federal Regulation Part 50, 56 and 312. 
Appendix B Department of Health approval letter

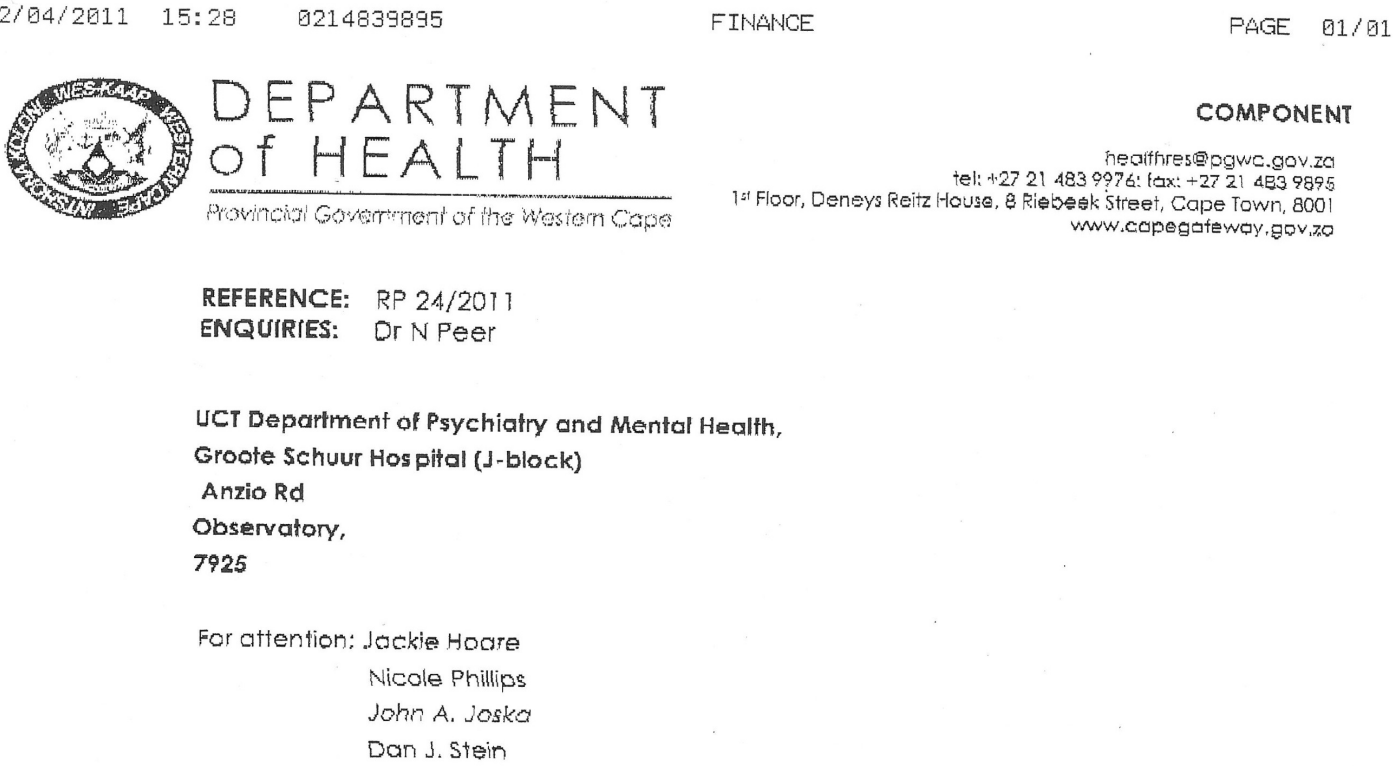

REFERENCE: RP 2A/2011

ENQUIRIES: OI N PEer

UCT Department of Psychiatry and Mental Health.

Groote schuur Hos pital (J-block)

Anzio Rd

Observatory,

7925

For attention: Jockie Hoare

Nicole Phillips

John A. Joska

Dan J. Stein

Re: A Diffusion tensor Imaging and Neurocognitive Study of HAART-näive and HAART-treated Chlldren in Cape Town

Thank you for submitting your proposal to unciertake the above-mentioned study. We are pleased to inform you that the department has granted you approval for your research. Please contact the following people to crssist you with any further enquiries.

$\begin{array}{lll}\text { Khayelitsha site C (Nolungile) } & \text { Sr Sheila Mccloen } & \text { (021) } 3746063 \\ \text { Mitchells Plein CHC } & \text { Ms Zethu Xapile } & (021) 4609100\end{array}$

Kindly ensure that the following are adhered to:

1. Arrangements can be made with managers, providing that normal octivities of requested facilities are not interpupted.

2. Researchers, in accessing provincial health facilities, are expressing consent to provide the department with on electronic copy of the find report within six months of completion of research. This can be submitted to the provinciel Research Co-prdinator (healthres@pgwc.gov.zo).

3. The reference number above thould be queted in all future correspondence.

We look forward to hearing from you.

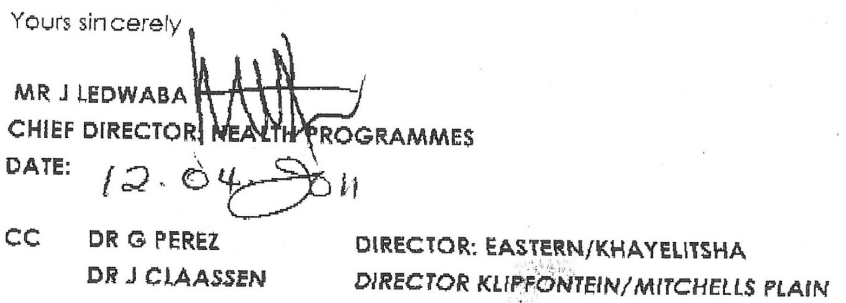

The Afrikans or Xhosa version of this documant is gvoilobia om request. 
REFERENCE: 20100614-0059

ENQUIRIES: Dr A T Wyngaard

Dr Jackie Hoare

Department of Psychology

UCT

Rondebosch

7700

\section{Dear Dr Jackie Hoare}

RESEARCH PROPOSAL: THE NEUROPSYCHOLOGICAL AND BEHAVIOURAL PROFILES OF HIVINFECTED HAART-NAIIVE CHILDREN

Your application to conduct the above-mentioned research in schools in the Western Cape has been approved subject to the following conditions:

1. Principals, educators and learners are under no obligation to assist you in your investigation.

2. Principals, educators, learners and schools should not be identifiable in any way from the results of the investigation.

3. You make all the arrangements concerning your investigation

4. Approval for projects should be conveyed to the District Director of the schools where the project will be conducted.

5. Educators' programmes are not to be interrupted.

6. The Study is to be conducted from 14 January 2013 till $\mathbf{3 0}$ September $\mathbf{2 0 1 3}$

7. No research can be conducted during the fourth term as schools are preparing and finalizing syllabi for examinations (October to December).

8. Should you wish to extend the period of your survey, please contact Dr A.T Wyngaard at the contact numbers above quoting the reference number?

9. A photocopy of this letter is submitted to the principal where the intended research is to be conducted.

10. Your research will be limited to the list of schools as forwarded to the Western Cape Education Department.

11. A brief summary of the content, findings and recommendations is provided to the Director: Research Services.

12. The Department receives a copy of the completed report/dissertation/thesis addressed to:

The Director: Research Services

Western Cape Education Department

Private Bag X9114

CAPE TOWN

8000

We wish you success in your research.

Kind regards.

Signed: Dr Audrey T Wyngaard

for: HEAD: EDUCATION

DATE: 13 September 2012

Lower Parliament Street, Cape Town, 8001

tel: +27214679272 fax: 0865902282

Safe Schools: 0800454647
Private Bag X9114, Cape Town, 8000

Employment and salary enquiries: 0861923322

www.westerncape.gov.za 
Appendix D Consent form HIV-infected child participants

PATIENT INFORMATION AND CONSENT FORM

FOR THE STUDY

Diffusion Tensor Imaging of HIV-positive Children and Their Psychocognitive and Behavioural Profiles.

HIV Positive patients

\section{Principal Investigator: Dr J Hoare}

Dear Participant

You and your child are requested to participate in a medical research study that is being done at Red Cross Children's Hospital in the School of Child and Adolescent Health, University of Cape Town. The following describes the study and you and your child's role. Please take some time to read the information presented here carefully, and feel free to ask any questions.

\section{Background}

We are doing a study on how HIV affects children's learning, development and behaviour. We want to compare tests of development (learning, memory, language and attention), psychosocial scales (trauma, life events, depression, anxiety and adaptability) and brain scans from children with HIV to children who do not have HIV.

If you are willing to allow your child to participate in this study, your child must be HIV positive and currently not physically ill.

HIV infection may cause slow development in a child. This can be either because of the virus itself or infections that the child may get. Even if a child seems well and is going to school, the HIV infection may affect some functions - like interfering with learning, with good memory, with doing mathematics, and with attention and behaviour.

We also want to learn about how caring for a child affects you as a parent. Parents, who have to care of a HIV-positive child, may experience more stress and difficulties than parents whose children do not have HIV. We want to compare test of parental stress of parents of children who are HIVpositive, to parents of children who are HIV-negative.

Children are often exposed to different kinds of trauma under various circumstances. We would like to find out more about the kinds of trauma certain children may experience.

\section{Purpose of the Study}

The aim of this study is to measure tests of development (learning, memory, language, attention) and tests of behaviour and brain scans in healthy HIV-positive children and in healthy HIV negative children. The HIV-positive children's performance will be compared to the performance of healthy HIV-negative children. This will improve our understanding and management of children with HIV. 


\section{Procedures in the Study}

Your involvement in the study will require you to visit the study doctor/team on three occasions. Two of the sessions will take place at Red Cross Children's Hospital (RXH), and during these sessions neuropsychological, developmental and behavioural tasks will be completed by your child. This includes the brain scan, but this will be done at Tygerberg Hospital.

\section{Confirmation of HIV diagnosis}

If you are invited to participate in this study, it means that your child has already been diagnoses as being HIV positive, and has been referred to this study. Your child is unique in that he/she will have acquired the infection via mother to child transmission, and not via a blood transfusion or unhygienic needles.

Your child is currently attending a clinic for regular checkups. With your permission, we will contact the clinic which you and your child are attending to gain access to information in your clinic folders. During the course of your participation you will be asked certain medical questions regarding your child most recent CD4 count, viral load, and current treatment regime.

\section{Neuropsychological and psychological testing}

The study research assistant will ask your child to complete a number of pencil and paper tests which involve some writing and drawing as we tests their memory, concentration and planning abilities. Many of these are like a normal IQ test that your child may have completed at school. All of these tests are important and will help us to determine if HIV has any effects on these aspects for your child's brain. This session will take approximately $2 \frac{1}{2}-3$ hours long. At another session you child will be asked questions about what kinds of things they have experienced in their everyday lives, as well as questions about their emotional state.

While your child completes these tasks, we will ask you as the parent / guardian to complete psychological measures pertaining to your child's overall development, as well as your experiences as a parent. These tests are important and will help us to determine the amount of stress and anxiety you may experience as a parent, and how this relates to your child's development.

\section{Brain scanning procedure}

All brain scans will be done at a specialized facility at Tygerberg Hospital. A special brain scan (an MRI scan) will be done on your child - this examination is not harmful and it is not painful. Your child will be asked to lie still on a special bed while the scanner takes the pictures of your child's head - this will be for a maximum of 30 minutes. Some children may find the machine a bit scary. If your child is very anxious or scared or unable to lie still for that long, we will not continue with the examination.

\section{Neurological examination}

You child will be required to undergo a neurological examination which will be performed by a study doctor. The purpose of this examination is to check that your child's sensory and motor responses, and also their reflexes, are functioning properly and that there is no damage to their nervous system. To test this, the doctor will ask your child to do a series of playful activities, for example touching their nose or their ankles. These tasks are not harmful to your child. If your child is anxious, you may accompany him/her in the examination room. 


\section{Procedure for drawing of bloods}

This part of the study involves the long-term storage of DNA (genetic) taken from a sample of your child's blood for future analysis. Genetic material, also called DNA, can be obtained from small samples of blood. Previous studies have shown that HIV infection can have damaging effects on the brain. We are however unsure as to how serious these effects may be in young children. In this part of the study, we hope one day to be able to use genetic material, such as we will be collecting, to assist us in identifying genes that will tell is what people may be particularly vulnerable to experience harmful effects, and what genetic patterns are likely to make people more susceptible to becoming infected with the HIV virus. Before the brain scan is done, a registered nurse will draw a small amount of blood from your child. This procedure will not be harmful to your child. Your child may feel a light prick when the needle is inserted into his/her arm, but will not experience any pain. The needle is connected to a thin plastic pipe and the blood then flows into a small blood sample tube. The test will require about 1 teaspoon of blood, and is performed only once.

Your blood will only be used for genetic research that is directly related to this study looking and diffusion tensor in HIV-infected children. Also if the researchers wish to use your stored blood for additional research in this field they will be required to apply for permission to do so from the Human Research Ethics Committee at UCT. If you do not wish your blood specimen to be stored after this research study is completed you will have an opportunity to request that it be discarded when you sign this consent form.

\section{Follow ups}

You and your child may be asked to attend a follow up session. If you are asked to come for a follow up, it will be one year from the date of your first enrollment to this study. The study procedures for the follow up, will be the same as for this time.

\section{Your Part in the Study}

While your child is being tested by members of the study team, you will also be asked to completed questions by another member of the study. You will complete a general demographics form, and other psychological tests pertaining to your child's mental health and yours. These tests are not harmful, but may ask some sensitive questions about your life. Our researchers will do all they can to emotionally support you while you complete these forms. It is important for us that you answer these questions truthfully, so that we can better understand you as a parent, and your needs.

For the first session, a trained research assistant will interview your child at RXH. During this session your child will complete the neuropsychological tasks previously described. During the second session, a registered social worker will interview your child about their behavioural and emotional well-being. Your child will then be given another appointment to go Tygerberg hospital, on a day that is convenient for you, where the brain scan will be done. We will try to arrange these sessions so as to not interfere with your child's normal school routine. These sessions may be booked after school hours where possible. Transport money and food vouchers will be provided for you and your child for each these visits.

\section{Risks to You and Your Child}

There are only low or minimal risks associated with your participation in this study. If you feel tired at any point during any of the visits, you should please ask your study doctor/psychologist for a rest. 
If for some reason you are unable to complete a visit on a particular day we may reschedule to complete the assessments at another time.

There are no direct risks in having blood taken for genetic testing.

Furthermore, there are no known risks for your child for either the psychological tests or the brain scan. The brain scan does not involve any radiation.

\section{Benefits to You and Your Child}

Although there is no direct benefit for you or your child, the results of this research may help to inform us to what the common school and behaviour problems are that healthy HIV-positive children can have. This will help us to decide if we need to consider extra treatments and/or interventions for these children.

\section{Confidentiality}

You and your child's test results will be kept confidential (private) and will only be used by the members of this study for the purpose of research. If any information from this study gets published, we will make sure that your personal details will remain confidential at all times.

This study has been approved by the Committee for Human Research of the University of Cape Town (UCT). It will be conducted according to Medical Research Council guidelines on good clinical practice (2003) as well as the Declaration of Helsinki Guidelines (Edinburgh, 2000), which provide detailed guidelines that relate to the ethical conduct of studies involving human subjects.

\section{Voluntary Participation}

You and your child's participation are entirely voluntary. You or your child is not under any obligation to participate. If you choose not to allow your child to participate, it will not affect you or your child negatively or prevent your right to future health care services. You have the right to withdraw your child from the study at any time.

You have the right to ask questions at any time about any aspect of the study. If you have any queries, you can contact Jackie Hoare on 021404 2134/2164

You are entitled to a signed copy of this document.

If you agree to take part, please complete the following section: 


\section{ASSENT OF MINOR}

I (Name of Child/Minor) have been invited to take part in the above research project entitled: Diffusion Tensor Imaging of HIV-positive Children and Their Psychocognitive and Behavioural Profiles.

The study doctor/nurse and my parents have explained the details of the study to me and I understand what they have said to me.

- They have also explained that this study will involve 3 assessments which include interviews, filling questionnaires, a physical examination, blood sampling, and a brain scan.

- I also know that I am free to withdraw from the study at any time if I am unhappy.

- By writing my name below, I voluntarily agree to take part in this research project. I confirm that I have not been forced either by my parents or doctor to take part.

Name of child (To be written by the child if possible) 


\section{DECLARATION BY PARENT/LEGAL GUARDIAN}

By signing below, I (name of parent/legal guardian) agree to allow my child (name of child) who is years old,

to take part in a research study entitled: Diffusion Tensor Imaging of HIV-positive Children and Their Psychocognitive and Behavioural Profiles.

I declare that:

- I have read or had read to me this information and consent form and that it is written in a language with which I am fluent and comfortable.

- If my child is older then 7 years, he/she must agree to take part in the study and his/her ASSENT must be recorded on this form.

- I have had a chance to ask questions and all my questions have been adequately answered.

- I understand that taking part in this study is voluntary and I have not been pressurised to let my child take part.

- I may choose to withdraw my child from the study at any time and my child will not be penalised or prejudiced in any way.

- My child may be asked to leave the study before it has finished if the study doctor or researcher feels it is in my child's best interests, or if my child does not follow the study plan as agreed to.

- I understand that genetic material will be collected from blood samples

I agree that my child's blood sample can be stored for research purposes, subject to the approval of the Human Research Ethics Committee (HREC) of UCT, provided that all information is kept confidential. I can choose to request at any time that my stored sample be destroyed. I have the right to receive confirmation that my request has been carried out.

OR

Please destroy my blood sample as soon as the current research project has been completed. (Tick the option you choose)

Signed at (place) on $($ date $)$ 20

Signature of parent/legal guardian 


\section{DECLARATION BY INVESTIGATOR}

I (name) declare that:

- I explained the information in this document to (name of child and parent)

I encouraged him/her to ask questions and took adequate time to answer them.

- I am satisfied that he/she adequately understand all aspects of the research, as discussed above.

- I did/did not use an interpreter (if an interpreter is used, then the interpreter must sign the declaration below).

Signed at (place) on (date) 20

Signature of investigator

\section{DECLARATION BY INTERPRETER}

I (name) - declare that:

- I assisted the investigator (name) to explain the information in this document to (name of parent/legal guardian) using the language medium of Afrikaans / Xhosa.

- We encouraged him/her to ask questions and took adequate time to answer them.

- I conveyed a factually correct version of what was related to me.

- I am satisfied that the parent/legal guardian fully understands the content of this informed consent document and has had all his/her questions satisfactorily answered.

Signed at (place) on (date) 20 
Appendix E Consent form HIV-negative child participants

\title{
PATIENT INFORMATION AND CONSENT FORM
}

\author{
FOR THE STUDY
}

\section{Diffusion Tensor Imaging of HIV Affected Children and Their Psychocognitive and Behavioural Profiles.}

HIV Negative controls

Principle Investigator: Dr J Hoare

Dear Participant

You and your child are requested to participate in a medical research study that is being done at Red Cross Children's Hospital in the School of Child and Adolescent Health, University of Cape Town. The following describes the study and you and your child's role. Please take some time to read the information presented here carefully, and feel free to ask any questions.

\section{Background}

We are doing a study on how HIV affects children's learning, development and behaviour. We want to compare tests of development (learning, memory, language and attention), psychosocial scales (trauma, life events, depression, anxiety and adaptability) and brain scans from children with HIV to children who do not have HIV.

You may participate in this study if your child is healthy and not HIV positive.

Infection may cause slow development in a child. This can be either because of the virus itself or infections that the child may get. Even if a child seems well and is going to school, the infection may affect some functions - like interfering with learning, with good memory, and with attention and behaviour.

We also want to learn about how caring for a child affects you as a parent. Parents, who have to care of a positive child, may experience more stress and difficulties than parents who have children who are negative. We want to compare test of parental stress of parents of children who are negative, to parents of children who are positive.

Children are often exposed to different kinds of trauma under various circumstances. We would like to find out more about the kinds of trauma certain children may experience.

\section{Purpose of the Study}

The aim of this study is to measure tests of development (learning, memory, language, attention) and tests of behaviour and brain scans in healthy positive children and in healthy negative children. The positive children's performance will be compared to the performance of healthy negative children. This will improve our understanding and management of children with HIV. 


\section{Procedures in the Study}

Your involvement in the study will require you to visit the study doctor/team on three occasions. Two of the sessions will take place at Red Cross Children's Hospital (RXH), and during these sessions neuropsychological, developmental and behavioural tasks will be completed by your child. The brain scan will be done at the third session, and this will take place at Tygerberg Hospital's (TBH) Cape Universities Brain Imaging Center (CUBIC).

\section{Neuropsychological and psychological testing}

The study research assistant will ask your child to complete a number of pencil and paper tests which involve some writing and drawing as we tests their memory, concentration and planning abilities. Many of these are like a normal IQ test that your child may have completed at school. All of these tests are important and will help us to determine if HIV has any effects on these aspects for your child's brain. This session will take approximately $2 \frac{1}{2}-3$ hours long. At another session you child will be asked questions about what kinds of things they have experienced in their everyday lives, as well as questions about their emotional state.

While your child completes these tasks, we will ask you as the parent / guardian to complete psychological measures pertaining to your child's overall development, as well as your experiences as a parent. These tests are important and will help us to determine the amount of stress and anxiety you may experience as a parent, and how this relates to your child's development.

\section{Brain scanning procedure}

All brain scans will be done at a specialized facility at Tygerberg Hospital. A special brain scan (an MRI scan) will be done on your child - this examination is not harmful and it is not painful. Your child will be asked to lie still on a special bed while the scanner takes the pictures of your child's head - this will be for a maximum of 45 minutes. During that time your child may rest and close his/her eyes. Having an MRI scan done is a safe procedure if you and your child have been screened correctly for the presence of any magnetic material on or inside you such as pace-makers, surgical clips and metal objects. A formal screen for this will be done by one of the study research assistants prior to the scanning session. When the magnet inside the machine is switched on, it will make some loud banging noises. At this time you will feel nothing and the noise is not harmful to you or your child in any way. Your child will be given soft ear plugs to wear during the procedure to minimize possible discomfort associated with this experience.

Some children may find the machine a bit frightening. If your child is very anxious or scared, you will be allowed to accompany your child inside the scanning room. We will make sure that it is safe for both you and your child to go inside the MRI scanning room and to undergo scanning. Your child may feel slightly dizzy immediately after the scan. This is completely normal. The radiographers at the scanning center are qualified and trained to be alert to the effects of the scanning procedure on participants. Your child's need will be attended to immediately, should the need arise. We will make every effort to ensure that your child is comfortable doing the scan. Materials will be provided to prepare your child before the scan, for example a flow diagram for the scanning procedure, as well as a video. If your child is still afraid or unable to lie still for that long, we will not continue with the examination. 


\section{Follow ups}

You and your child may be asked to attend a follow up session. If you are asked to come for a follow up, it will be one year from the date of your first enrollment to this study. The study procedures for the follow up, will be the same as for this time.

\section{Your Part in the Study}

While your child is being tested by members of the study team, you will also be asked to completed questions by another member of the study. You will complete a general demographics form, and other psychological tests pertaining to your child's mental health and yours. These tests are not harmful, but may ask some sensitive questions about your life. Our researchers will do all they can to emotionally support you while you complete these forms. It is important for us that you answer these questions truthfully, so that we can better understand you as a parent, and the difficulties you experience while caring for your child.

For the first session, a trained research assistant will interview your child at RXH. During this session your child will complete the neuropsychological tasks previously described. During the second session, a registered social worker will interview your child about their behavioural and emotional well-being. Your child will then be given another appointment to go Tygerberg hospital, on a day that is convenient for you, where the brain scan will be done. We will try to arrange these sessions so as to not interfere with your child's normal school routine. These sessions may be booked after school hours where possible. Transport money and food vouchers will be provided for you and your child for each these visits.

\section{Risks to You and Your Child}

If you or your child feels tired at any point during any of the visits, you should ask your study doctor/psychologist for a rest. If for some reason you are unable to complete a visit on a particular day we may reschedule to complete the assessment at another time.

Furthermore, there are no known risks for your child for either the psychological tests or the brain scan. The brain scan does not involve any radiation.

\section{Benefits to You and Your Child}

Although there is no direct benefit for you or your child, the results of this research may help to inform us to what the common school and behaviour problems are that healthy HIV-positive children can have. This will help us to decide if we need to consider extra treatments and/or interventions for these children.

We acknowledge that we cannot provide intervention or treatment, as part of this study. If it is detected that your child has developmental delay, we will provide you will a detailed report, and with your permission we will forward it to the relevant educational department to be dealt with accordingly. A detailed report will be important in determining what type of intervention your child may need. Further treatment for your child will be at your own expense.

\section{Confidentiality}

You and your child's test results will be kept confidential (private) and will only be used by the members of this study for the purpose of research. If any information from this study gets published, we will make sure that your personal details will remain confidential at all times. 
This study has been approved by the Human Research Ethics Committee (021 406 6492) of the University of Cape Town (UCT). It will be conducted according to Medical Research Council guidelines on good clinical practice (2003) as well as the Declaration of Helsinki Guidelines (Edinburgh, 2008), which provide detailed guidelines that relate to the ethical conduct of studies involving human subjects.

\section{Voluntary Participation}

You and your child's participation are entirely voluntary. You or your child is not under any obligation to participate. If you choose not to allow your child to participate, it will not affect you or your child negatively or prevent your right to future health care services.

You have the right to withdraw your child from the study at any time.

You have the right to ask questions at any time about any aspect of the study. If you have any queries, you can contact Jackie Hoare on 021404 2134/2164.

You are entitled to a signed copy of this document.

If you agree to take part, please complete the following section: 


\section{ASSENT OF MINOR}

I (Name of Child/Minor) have been invited to take part in the above research project entitled: Diffusion Tensor Imaging of HIV-positive Children and Their Psychocognitive and Behavioural Profiles.

The study doctor/nurse and my parents have explained the details of the study to me and I understand what they have said to me.

- They have also explained that this study will involve 3 assessments which include interviews, filling questionnaires, a physical examination, and a brain scan.

- I also know that I am free to withdraw from the study at any time if I am unhappy.

- By writing my name below, I voluntarily agree to take part in this research project. I confirm that I have not been forced either by my parents or doctor to take part.

Name of child (To be written by the child if possible) 


\section{DECLARATION BY PARENT/LEGAL GUARDIAN}

By signing below, I (name of parent/legal guardian) agree to allow my child (name of child) who is years old,

to take part in a research study entitled: Diffusion Tensor Imaging of HIV-positive Children and Their Psychocognitive and Behavioural Profiles.

I declare that:

- I have read or had read to me this information and consent form and that it is written in a language with which I am fluent and comfortable.

- If my child is older than 7 years, he/she must agree to take part in the study and his/her ASSENT must be recorded on this form.

- I have had a chance to ask questions and all my questions have been adequately answered.

- I understand that taking part in this study is voluntary and I have not been pressurised to let my child take part.

- I may choose to withdraw my child from the study at any time and my child will not be penalised or prejudiced in any way.

- My child may be asked to leave the study before it has finished if the study doctor or researcher feels it is in my child's best interests, or if my child does not follow the study plan as agreed to.

Signed at (place) on (date) 20

Signature of parent/legal guardian 


\section{DECLARATION BY INVESTIGATOR}

I (name) declare that:

- I explained the information in this document to (name of child and parent)

I encouraged him/her to ask questions and took adequate time to answer them.

- I am satisfied that he/she adequately understand all aspects of the research, as discussed above.

- I did/did not use an interpreter (if an interpreter is used, then the interpreter must sign the declaration below).

Signed at (place) on (date) 20

Signature of investigator

\section{DECLARATION BY INTERPRETER}

I (name) . declare that:

- I assisted the investigator (name) to explain the information in this document to (name of parent/legal guardian) using the language medium of Afrikaans/Xhosa.

- We encouraged him/her to ask questions and took adequate time to answer them.

- I conveyed a factually correct version of what was related to me.

- I am satisfied that the parent/legal guardian fully understands the content of this informed consent document and has had all his/her questions satisfactorily answered.

Signed at (place) on (date) 20

Signature of interpreter 
Appendix F AIDS Care Instructions for Authors

\section{Instructions for authors}

SCHOLARONE MANUSCRIPTS*

This journal uses ScholarOne Manuscripts (previously Manuscript Central) to peer review manuscript submissions. Please read the guide for ScholarOne authors before making a submission. Complete guidelines for preparing and submitting your manuscript to this journal are provided below.

Use these instructions if you are preparing a manuscript to submit to AIDS Care. To explore our journals portfolio, visit http://www.tandfonline.com/, and for more author resources, visit our Author Serviceswebsite.

AIDS Care considers all manuscripts on the strict condition that

- the manuscript is your own original work, and does not duplicate any other previously published work, including your own previously published work.

- the manuscript has been submitted only to AIDS Care; it is not under consideration or peer review or accepted for publication or in press or published elsewhere.

- the manuscript contains nothing that is abusive, defamatory, libellous, obscene, fraudulent, or illegal.

Please note that AIDS Care uses CrossCheck ${ }^{\mathrm{TM}}$ software to screen manuscripts for unoriginal material. By submitting your manuscript to AIDS Care you are agreeing to any necessary originality checks your manuscript may have to undergo during the peer-review and production processes.

Any author who fails to adhere to the above conditions will be charged with costs which AIDS Care incurs for their manuscript at the discretion of AIDS Care's Editors and Taylor \& Francis, and their manuscript will be rejected.

This journal is compliant with the Research Councils UK OA policy. Please see the licence options and embargo periods here.

\section{Contents List}

\section{Manuscript preparation}

1. General guidelines

2. Style guidelines

3. Figures

4. Graphical abstracts

5. Publication charges

- Submission fee

- $\quad$ Page charges

- Colour charges

6. Reproduction of copyright material

7. Supplemental online material

Manuscript submission

Copyright and authors' rights

Free article access

Reprints and journal copies

Open access

\section{Manuscript preparation}

\section{General guidelines}

$\uparrow$ Back to top. 
- Manuscripts are accepted in English. Any consistent spelling and punctuation styles may be used. Please use double quotation marks, except where "a quotation is 'within' a quotation". Long quotations of 40 words or more should be indented without quotation marks.

- You should prepare and upload two versions of your manuscript. One should be a complete text; the other should have all information identifying the author removed from files to allow them to be sent anonymously to referees. Upload the anonymised version as a "Main Document" and the complete text as a "File not for Review".

- Manuscript format should be in the style of the American Psychological Association (6th edition). Manuscripts should be double spaced, with ample margins of at least one inch. Footnotes to the text should be avoided wherever this is reasonably possible. All identifying information should be removed from the Manuscript Files for Review prior to submission, as detailed above.

- Captions for figures should be provided and should make interpretation possible without reference to the text. Captions should include keys to symbols.

- Units in tables should appear in parentheses in the column heading but not in the body of the table. Words or numerals should be repeated on successive lines; 'ditto' or 'do' should not be used.

- Proofs including proofs of illustrations are supplied for checking and making essential corrections, not for general revision or alteration. Proofs should be corrected and returned within 3 days of receipt.

- Manuscripts can be in these formats: (i) Short reports not exceeding 1500 words; (ii) Original articles of 1,500-3,000 words. The word count does not include the abstract, references, captions, endnotes, figures and tables. Manuscripts that greatly exceed this will be critically reviewed with respect to length. Authors should include a word count with their manuscript.

- Manuscripts should be compiled in the following order: title page (including Acknowledgements as well as Funding and grant-awarding bodies); abstract; keywords; main text; references; appendices (as appropriate); table(s) with caption(s) (on individual pages); figure caption(s) (as a list).

Please supply all details required by any funding and grant-awarding bodies as an acknowledgement in a separate Funding paragraph as follows:

For single agency grants

This work was supported by the <Funding Agency $>$ under Grant < number xxxx>.

For multiple agency grants

This work was supported by the <Funding Agency \#1> under Grant <number xxxx>; <Funding Agency \#2> under Grant <number xxxx>; and <Funding Agency \#3> under Grant <number xxxx>.

- $\quad$ Abstracts of 300 words are required for all manuscripts submitted.

- Each manuscript should have 5 to 6 keywords.

- Search engine optimization (SEO) is a means of making your article more visible to anyone who might be looking for it. Please consult our guidance here.

- Section headings should be concise.

- All authors of a manuscript should include their full names, affiliations, postal addresses, telephone numbers and email addresses on the cover page of the manuscript. One author should be identified as the corresponding author. Please give the affiliation where the research was conducted. If any of the named coauthors moves affiliation during the peer review process, the new affiliation can be given as a footnote. Please note that no changes to affiliation can be made after the manuscript is accepted. Please note that the email address of the corresponding author will normally be displayed in the article PDF (depending on the journal style) and the online article.

- $\quad$ All persons who have a reasonable claim to authorship must be named in the manuscript as co-authors; the corresponding author must be authorized by all co-authors to act as an agent on their behalf in all matters pertaining to publication of the manuscript, and the order of names should be agreed by all authors.

- Biographical notes on contributors are not required for this journal.

- $\quad$ Please supply all details required by any funding and grant-awarding bodies as an Acknowledgement on the title page of the manuscript, in a separate paragraph, as follows:

- For single agency grants: "This work was supported by the [Funding Agency] under Grant [number xxxx]."

- $\quad$ For multiple agency grants: "This work was supported by the [Funding Agency 1] under Grant [number $\mathrm{xxxx}$ ]; [Funding Agency 2] under Grant [number xxxx]; and [Funding Agency 3] under Grant [number $x x x x] . "$

- $\quad$ Authors must also incorporate a Disclosure Statement which will acknowledge any financial interest or benefit they have arising from the direct applications of their research.

- For all manuscripts non-discriminatory language is mandatory. Sexist or racist terms must not be used.

- $\quad$ Authors must adhere to SI units. Units are not italicised. 
- When using a word which is or is asserted to be a proprietary term or trade mark, authors must use the symbol $($ ) or TM.

2. Style guidelines

$\uparrow$ Back to top.

- Description of the Journal's article style.

- Description of the Journal's reference style.

- $\quad$ Guide to using mathematical scripts and equations.

- Word templates are available for this journal. If you are not able to use the template via the links or if you have any other template queries, please contact authortemplate@tandf.co.uk.

- Authors must not embed equations or image files within their manuscript

3. Figures

$\uparrow$ Back to top.

- $\quad$ Please provide the highest quality figure format possible. Please be sure that all imported scanned material is scanned at the appropriate resolution: $1200 \mathrm{dpi}$ for line art, $600 \mathrm{dpi}$ for grayscale and $300 \mathrm{dpi}$ for colour.

- $\quad$ Figures must be saved separate to text. Please do not embed figures in the manuscript file.

- $\quad$ Files should be saved as one of the following formats: TIFF (tagged image file format), PostScript or EPS (encapsulated PostScript), and should contain all the necessary font information and the source file of the application (e.g. CorelDraw/Mac, CorelDraw/PC).

- $\quad$ All figures must be numbered in the order in which they appear in the manuscript (e.g. Figure 1, Figure 2). In multi-part figures, each part should be labelled (e.g. Figure 1(a), Figure 1(b)).

- $\quad$ Figure captions must be saved separately, as part of the file containing the complete text of the manuscript, and numbered correspondingly.

- The filename for a graphic should be descriptive of the graphic, e.g. Figure1, Figure2a.

4. Graphical Abstracts

$\uparrow$ Back to top.

AIDS Care authors now have the option of including a graphical abstract in their paper. The purpose of a graphical abstract is to give the reader a clear idea of the content of the article by means of an appropriate image.

- The graphical abstract should have a maximum width of 525 pixels. If your image is narrower than 525 pixels we recommend placing this on a white background 525 pixels wide to ensure the dimensions are maintained.

- $\quad$ Graphical abstracts must be saved separate to text. Please do not embed graphical abstracts in the manuscript file. Files should be saved as one of the following formats: .jpg, .png, or .gif.

- The file name for a graphical abstract should be descriptive, e.g. GraphicalAbstract1

5. Publication charges

$\uparrow$ Back to top.

\section{Submission fee}

There is no submission fee for AIDS Care.

\section{Page charges}

There are no page charges for AIDS Care.

\section{Colour charges}

Colour figures will be reproduced in colour in the online edition of the journal free of charge. If it is necessary for the figures to be reproduced in colour in the print version, a charge will apply. Charges for colour figures in print are $£ 250$ per figure (\$395 US Dollars; \$385 Australian Dollars; 315 Euros). For more than 4 colour figures, figures 5 and above will be charged at $£ 50$ per figure ( $\$ 80$ US Dollars; $\$ 75$ Australian Dollars; 63 Euros).

Depending on your location, these charges may be subject to Value Added Tax.

\section{Reproduction of copyright material}

$\uparrow$ Back to top. 
If you wish to include any material in your manuscript in which you do not hold copyright, you must obtain written permission from the copyright owner, prior to submission. Such material may be in the form of text, data, table, illustration, photograph, line drawing, audio clip, video clip, film still, and screenshot, and any supplemental material you propose to include. This applies to direct (verbatim or facsimile) reproduction as well as "derivative reproduction" (where you have created a new figure or table which derives substantially from a copyrighted source).

You must ensure appropriate acknowledgement is given to the permission granted to you for reuse by the copyright holder in each figure or table caption. You are solely responsible for any fees which the copyright holder may charge for reuse.

The reproduction of short extracts of text, excluding poetry and song lyrics, for the purposes of criticism may be possible without formal permission on the basis that the quotation is reproduced accurately and full attribution is given.

For further information and FAQs on the reproduction of copyright material, please consult our Guide.

\section{Supplemental online material}

$\uparrow$ Back to top.

Authors are encouraged to submit animations, movie files, sound files or any additional information for online publication.

\section{- Information about supplemental online material}

\section{Manuscript submission}

\section{$\uparrow$ Back to top.}

All submissions should be made online at the AIDS Care Scholar One Manuscripts website. New users should first create an account. Once logged on to the site, submissions should be made via the Author Centre. Online user guides and access to a helpdesk are available on this website.

Manuscripts may be submitted in any standard editable format, including Word and EndNote. These files will be automatically converted into a PDF file for the review process. LaTeX files should be converted to PDF prior to submission because ScholarOne Manuscripts is not able to convert LaTeX files into PDFs directly. All LaTeX source files should be uploaded alongside the PDF.

Click here for information regarding anonymous peer review.

\section{Copyright and authors' rights}

\section{$\uparrow$ Back to top.}

To assure the integrity, dissemination, and protection against copyright infringement of published articles, you will be asked to assign us, via a Publishing Agreement, the copyright in your article. Your Article is defined as the final, definitive, and citable Version of Record, and includes: (a) the accepted manuscript in its final form, including the abstract, text, bibliography, and all accompanying tables, illustrations, data; and (b) any supplemental material hosted by Taylor \& Francis. Our Publishing Agreement with you will constitute the entire agreement and the sole understanding between you and us; no amendment, addendum, or other communication will be taken into account when interpreting your and our rights and obligations under this Agreement.

Copyright policy is explained in detail here.

\section{Free article access}

$\uparrow$ Back to top.

As an author, you will receive free access to your article on Taylor \& Francis Online. You will be given access to the My authored works section of Taylor \& Francis Online, which shows you all your published articles. You can easily 
view, read, and download your published articles from there. In addition, if someone has cited your article, you will be able to see this information. We are committed to promoting and increasing the visibility of your article and have provided guidance on how you can help. Also within My authored works, author eprints allow you as an author to quickly and easily give anyone free access to the electronic version of your article so that your friends and contacts can read and download your published article for free. This applies to all authors (not just the corresponding author).

\section{Reprints and journal copies}

$\uparrow$ Back to top.

Article reprints can be ordered through Rightslink $\&$ when you receive your proofs. If you have any queries about reprints, please contact the Taylor \& Francis Author Services team at reprints@tandf.co.uk. To order a copy of the issue containing your article, please contact our Customer Services team at Adhoc@tandf.co.uk.

\section{Open Access}

$\uparrow$ Back to top.

Taylor \& Francis Open Select provides authors or their research sponsors and funders with the option of paying a publishing fee and thereby making an article permanently available for free online access - open access immediately on publication to anyone, anywhere, at any time. This option is made available once an article has been accepted in peer review.

Full details of our Open Access programme

Last updated 20/02/2014

\section{- Taylor \& Francis}

Visit our Author Services website for further resources and guides to the complete publication process and beyond. 
Appendix G Socio-demographic Questionnaire

DEMOGRAPHICS QUESTIONNAIRE

Please circle where appropriate. Please describe extra information.

A. PARENT / CAREGIVER DEMOGRAPHICS

Gender: MALE $\quad$ FEMALE

Age:

DOB:

Marital status: $\quad$ MARRIED

SINGLE DIVORCED WIDOWED

Race: WHITE COLOURED

BLACK AFRICAN

OTHER

Are you dependent on a government grant?

YES

$\mathrm{NO}$

If yes, please specify:

B. OBSTETRICS HISTORY

Any birth complications:

YES

$\mathrm{NO}$

If yes, please specify:

Emergency C-section:

YES

NO

If yes, please explain:

Routine check-ups followed:

YES

NO

If no, why not:

Alcohol use during pregnancy:

YES

NO

If yes, please explain (frequency and quantity):

Drug use during pregnancy:

YES

$\mathrm{NO}$

If yes, please explain (quantity, frequency and type):

C. CHILD / PATIENT DEMOGRAPHICS

Sex:

MALE

FEMALE

Age:

DOB:

Race: WHITE

COLOURED

BLACK AFRICAN

OTHER

If other, please specify: 
Religion:

Home Language: ENGLISH AFRIKAANS isiXhosa OTHER

Other languages in which your child is fluent:

\section{CHILD / PATIENT MEDICAL HISTORY}

Significant / traumatic head injuries:

$\mathrm{NO}$

If yes, please specify the following:

When/how long ago:

Was child unconscious (could not wake child up):

Was child hospitalised and for how long:

Did the child require stitches:

Brain scans done and when:

Previous Alcohol use:

YES

$\mathrm{NO}$

Current Alcohol use:

YES

$\mathrm{NO}$

If yes, please specify quantity and frequency:

Previous Drug use:

YES

NO

Current Drug use:

YES

NO

If yes, please specify quantity, frequency and type:

Has your child ever been diagnosed with any psychiatric illness: eg: depression, psychosis, anxiety, etc:

YES

\section{NO}

If yes, please specify:

Is your child currently receiving treatment for a psychiatric illness: YES

NO

If yes, please explain: 
Please explain your child's current HAART treatment regime:

First line / Second line / Third line

Describe:

Has your child had any HIV related illnesses:

YES

NO

If yes, please specify: eg: $\mathrm{TB}$, pneumonia, meningitis, etc.

Is your child currently receiving treatment for an HIV related illness: YES

NO

If yes, please explain:

Has your child had any surgical procedures done? Please explain:

Does your child have any other medical conditions:

YES

NO

If yes, please specify: eg: diabetes, asthma, epilepsy, etc:

\section{EDUCATION LEVEL OF CHILD}

Highest grade completed at school:

Current grade:

Current School setting:

RURAL

URBAN

Name of school:

Has he/she repeated any grades at school?

YES

NO

If yes, which grade(s):

Has your child ever (current or previous) had remedial help at school:

YES

NO

If yes, please provide more detail: 
If your child is not currently attending school, please specify their daily activities. Are they at home? At a care facility? Etc.

\section{E. GENERAL INFORMATION}

Which best describes the area you live in?

$\begin{array}{lll}\text { SURBURBAN URBAN RURAL TOWNSHIP } & \text { TH }\end{array}$

What is the name of the area you live in?

Living structure: Brick house / Shack / Wooden wendy house

If other, describe:

Size of the house (number of rooms in the house):

Number of people who live in the house:

Who lives in your house (e.g., father, mother, grandmother, etc):

Do you have the following amenities in your home:

i. Electricity / Gas

YES

$\mathrm{NO}$

ii. Adequate clothing for child

YES

$\mathrm{NO}$

iii. Enough food to eat for at least 2 meals per day YES

NO

iv. Child's own study/homework area or space

YES

$\mathrm{NO}$ 
Appendix H Child Behaviour Checklist Results across the HIV subgroups

Within the HIV-infected group, children were further divided into three subgroups: PHIV+ children who had never been on antiretroviral therapy (ART naïve), PHIV+ children on ART and PHIV+ children on ART with a confirmed diagnosis of HIV-related encephalopathy. Appendix H shows the CBCL results across the three HIV subgroups. Some variability was observed with respect to the distribution of total problem scores between these groups, with children on ART having fewer emotional and behavioural problems when compared to ART naïve and children on ART with encephalopathy $(\mathrm{F}=6.188, \mathrm{df}=2.75, \mathrm{p}<0.01)$. 